\title{
GOVERNMENT OF ZAMBIA
}

\section{ACT}

No. 2 of 2016

Date of Assent: 5th January, 2016

\section{An Act to amend the Constitution of Zambia.}

[ 5th January, 2016

ENACTED by the Parliament of Zambia.

Enactment

Short title

Cap. 1

Repeal and replacement of Preamble

\section{PREAMBle}

We, the People of Zambia:

AcKnowledge the supremacy of God Almighty;

Declare the Republic a Christian Nation while upholding a person's right to freedom of conscience, belief or religion;

UpHOLD the human rights and fundamental freedoms of every person;

Commit ourselves to upholding the principles of democracy and good governance;

RESOLVE to ensure that our values relating to family, morality, patriotism and justice are maintained and all functions of the State are performed in our common interest;

CONFIRM the equal worth of women and men and their right to freely participate in, determine and build a sustainable political, legal, economic and social order; 
RECOGNISE AND UPHOLD the multi-ethnic, multi-racial, multi-religious and multi-cultural character of our Nation and our right to manage our affairs and resources sustainably in a devolved system of governance;

Resolve that Zambia shall remain a unitary, multi-party and democratic sovereign State;

RECOGNISE AND HONOUR the freedom fighters who fought for the independence of our Nation in order to achieve liberty, justice and unity for the people of Zambia;

AND DIRECT that all State organs and State institutions abide by and respect our sovereign will;

\section{Do Hereby Solemnly Adopt and Give to Ourselves this Constitution:}

Repeal and replacement of Parts I and II

Supremacy

of

Constitution

3. The Constitution is amended by the repeal of Parts I and II and the substitution therefor of the following Parts:

\section{PART I \\ SuPREMACY OF CONSTITUTION}

1. (1) This Constitution is the supreme law of the Republic of Zambia and any other written law, customary law and customary practice that is inconsistent with its provisions is void to the extent of the inconsistency.

(2) An act or omission that contravenes this Constitution is illegal.

(3) This Constitution shall bind all persons in Zambia, State organs and State institutions.

(4) The validity or legality of this Constitution is not subject to challenge by or before a State organ or other forum.

(5) A matter relating to this Constitution shall be heard by the Constitutional Court.

Defence of Constitution

Continuous effect of Constitution
2. Every person has the right and duty to-

(a) defend this Constitution; and

(b) resist or prevent a person from overthrowing, suspending or illegally abrogating this Constitution.

3. The operation of this Constitution shall not be affected by an unlawful act to overthrow, suspend or illegally abrogate its provisions. 
4. (1) Zambia is a sovereign Republic under a constitutional form of governance.

Republic of

(2) The Republic consists of the territory defined in an Act of Parliament.

(3) The Republic is a unitary, indivisible, multi-ethnic, multi-racial, multi-religious, multi-cultural and multi-party democratic State.

(4) The Republic shall not be ceded in whole or in part.

(5) The Republic may enter into a union or other form of interstate organisation, which action shall not be construed as ceding the Republic.

5. (1) Sovereign authority vests in the people of Zambia, which may be exercised directly or through elected or appointed representatives or institutions.

(2) Power that is not conferred by or under this Constitution on any State organ, State institution, State officer, Constitutional office holder or other institution or person is reserved for the people.

(3) The people of Zambia shall exercise their reserved power through a referendum, as prescribed.

6. (1) The national symbols of the Republic are the-

(a) National Flag;

National

(b) National Anthem;

(c) Coat of Arms;

(d) Public Seal; and

(e) National Motto.

(2) The form, words, description and use of the national symbols shall be as prescribed.

7. The Laws of Zambia consist of-

(a) this Constitution;

(b) laws enacted by Parliament;

(c) statutory instruments;

(d) Zambian customary law which is consistent with this Constitution; and

(e) the laws and statutes which apply or extend to Zambia, as prescribed. 


\begin{tabular}{|c|c|}
\hline \multirow{4}{*}{$\begin{array}{l}\text { National } \\
\text { values and } \\
\text { principles }\end{array}$} & PART II \\
\hline & National V alues, Principles and Economic Policies \\
\hline & 8. The national values and principles are- \\
\hline & (a) morality and ethics; \\
\hline & (b) patriotism and national unity; \\
\hline & (c) democracy and constitutionalism; \\
\hline & $\begin{array}{l}\text { (d) human dignity, equity, social justice, equality and non- } \\
\text { discrimination; }\end{array}$ \\
\hline & (e) good governance and integrity; and \\
\hline & (f) sustainable development. \\
\hline
\end{tabular}

Application of national values and principles

Basis of economic policies

Repeal and replacement of Part IV
9. (1) The national values and principles shall apply to the -

(a) interpretation of this Constitution;

(b) enactment and interpretation of the law; and

(c) development and implementation of State policy.

(2) The President shall, once in every year, report to the National Assembly the progress made in the application of the values and principles specified under this Part.

10. (1) The Government shall create an economic environment which encourages individual initiative and self-reliance among the people, so as to promote investment, employment and wealth.

(2) The Government shall promote the economic empowerment of citizens so that they contribute to sustainable economic growth and social development.

(3) The Government shall promote local and foreign investment and protect and guarantee such investment through agreements with investors and other countries.

(4) The Government shall not compulsorily acquire an investment, except under customary international law and subject to Article 16 (1).

(5) Where the investment compulsorily acquired under clause (4) was made from the proceeds of crime no compensation shall be paid by the Government.

4. The Constitution is amended by the repeal of Part IV and the substitution therefor of the following Part: 


\section{PART IV}

\section{Citizenship}

33. A person who was a citizen of Zambia, immediately before the commencement of this Constitution, shall continue to be a citizen of Zambia and shall retain the same citizenship category from the date the citizenship was acquired.

34. Citizenship may be acquired by birth, descent, registration or adoption in accordance with this Part.

35. (1) A person born in Zambia is a citizen by birth if, at the date of that person's birth, at least one parent of that person is or was a citizen.

(2) A child found in Zambia who is, or appears to be, of not more than eight years of age and whose nationality and parents are not known, shall be presumed to be a citizen by birth.

(3) For the purposes of this Part, a person born aboard-

(a) a registered ship or aircraft of a country, shall be deemed to have been born in the country of registration of the ship or aircraft; or

(b) an unregistered ship or aircraft of a country, shall be deemed to have been born in that country.

36. A person born outside Zambia is a citizen by descent if, at the date of that person's birth, at least one parent of that person is or was a citizen by birth or descent.

37. (1) Subject to clause (2), a person is entitled to apply to the Citizenship Board of Zambia to be registered as a citizen if that person has attained the age of eighteen years and-

Categories of citizenship Citizenship

by birth

Existing citizenship
Citizenship by descent

Citizenship by registration

(a) was born in Zambia and has been ordinarily resident in Zambia for a period of at least five years;

(b) was born outside Zambia, has or had an ancestor who is, or was, a citizen and has been ordinarily resident in Zambia for a period of at least five years; or

(c) has been ordinarily resident in Zambia for a continuous period of at least ten years;

immediately preceding that person's application for registration, as prescribed. 
(2) Notwithstanding clause (1), a person who is, or was married to a citizen, for a period of at least five years, is entitled to apply to the Citizenship Board of Zambia, to be registered as a citizen, as prescribed.

Citizenship by adoption

Dual citizenship

Renunciation and deprivation of citizenship

Citizenship Board of Zambia

Entitlements of citizen

Responsibilities of citizen
38. A child who is not a citizen and who is adopted by a citizen shall be a citizen on the date of the adoption.

39. (1) A citizen shall not lose citizenship by acquiring the citizenship of another country.

(2) A citizen who ceased to be a citizen, before the commencement of this Constitution as a result of acquiring the citizenship of another country, shall be entitled to apply, as prescribed, to the Citizenship Board of Zambia, for citizenship and the Citizenship Board of Zambia shall bestow citizenship on that person.

40. (1) A citizen-

(a) may renounce citizenship as prescribed; or

(b) shall be deprived of citizenship if that citizenship was acquired by means of fraud, false representation or concealment of a material fact.

(2) The process and procedures to be followed by the Citizenship Board of Zambia when granting or depriving a person of citizenship shall be prescribed.

41. (1) There is established the Citizenship Board of Zambia.

(2) The composition, appointment and tenure of office of members of, and procedures to be followed by, the Citizenship Board of Zambia shall be prescribed.

42. A citizen is entitled to-

(a) the rights, privileges and benefits of citizenship as provided in this Constitution or as prescribed; and

(b) a document of identification issued by the State to citizens.

43. (1) A citizen shall -

(a) be patriotic to Zambia and promote its development and good image;

(b) pay taxes and duties lawfully due and owing to the State;

(c) protect and conserve the environment and utilise natural resources in a sustainable manner; 
(d) maintain a clean and healthy environment;

(e) provide national, defence and military service when called upon by the State; and

(f) co-operate with law enforcement agencies for the maintenance and enforcement of law and order.

(2) A citizen shall endeavour to-

(a) acquire basic understanding of this Constitution and promote its ideals and objectives;

(b) register and vote, if eligible, in national and local government elections and referenda;

(c) develop one's abilities to the greatest possible extent through acquisition of knowledge, continuous learning and the development of skills;

(d) foster national unity and live in harmony with others; and

(e) understand and enhance Zambia's place in the international community.

44. A reference in this Part to the citizenship of the parent of a person at the time of the birth of that person shall, in relation to a person born after the death of that person's parent, be construed

Reference to citizenship of parent as a reference to the citizenship of the parent at the time of the parent's death.

\section{PART V}

Representation of the People

\section{Electoral Systems and Process}

45. (1) The electoral systems provided for in Article 47 for the election of President, Member of Parliament or councillor shall ensure-

Principles of electoral systems and process

(a) that citizens are free to exercise their political rights;

(b) universal adult suffrage based on the equality of a vote;

(c) fair representation of the various interest groups in society; and

(d) gender equity in the National Assembly or council.

(2) The electoral process and system of administering elections shall ensure- 
(a) that elections are free and fair;

(b) that elections are free from violence, intimidation and corruption;

(c) independence, accountability, efficiency and transparency of the electoral process;

(d) a simple and practical system of voting and tabulating votes; and

(e) timely resolution of electoral disputes.

Franchise

Electoral systems

Electoral process

System for administering elections

Access to media

Independent candidates
46. A citizen who has attained the age of eighteen years is entitled to be registered as a voter and vote in an election by secret ballot.

47. (1) Elections to the office of President shall be conducted directly, under a majoritarian electoral system, where the winning candidate must receive more than fifty percent of the valid votes cast, and in accordance with Article 101.

(2) Elections to the National Assembly shall be conducted under a first-past-the-post electoral system in accordance with Article 68.

(3) Elections to councils shall be conducted under a first-pastthe-post electoral system, and in accordance with Articles 153 and 154.

(4) A constituency and a ward shall return only one member to the National Assembly and council, respectively.

48. The electoral process for electing a President, Member of Parliament or councillor shall be prescribed.

49. The system of administering elections shall be prescribed.

50. A political party and a candidate contesting an election shall have access to the media, especially during election campaigns.

51. A person is eligible for election as an independent candidate for a National Assembly seat if the person-

(a) is not a member of a political party and has not been a member of a political party for at least two months immediately before the date of the election; and 
(b) meets the qualifications specified in Article 70 for election as a Member of Parliament.

52. (1) A candidate shall file that candidate's nomination paper to a returning officer, supported by an affidavit stating that the candidate is qualified for nomination as President, Member of Parliament or councillor, in the manner, on the day, and at the time and place set by the Electoral Commission by regulation.

(2) A returning officer shall, immediately on the filing of a nomination paper, in accordance with clause (1), duly reject the nomination paper if the candidate does not meet the qualifications or procedural requirements specified for election to that office.

(3) The information contained in a nomination paper and affidavit shall be published by the Electoral Commission, as prescribed.

(4) A person may challenge, before a court or tribunal, as prescribed, the nomination of a candidate within seven days of the close of nomination and the court shall hear the case within twentyone days of its lodgement.

(5) The processes specified in clauses (1) to (4) shall be completed at least thirty days before a general election.

(6) Where a candidate dies, resigns or becomes disqualified in accordance with Article 70, 100 or 153 or a court disqualifies a candidate for corruption or malpractice, after the close of nominations and before the election date, the Electoral Commission shall cancel the election and require the filing of fresh nominations by eligible candidates and elections shall be held within thirty days of the filing of the fresh nominations.

53. (1) Where only one candidate is nominated for election Unopposed candidates as President, Member of Parliament or councillor, by the date and time set by the Electoral Commission for receiving nominations and at the close of the nomination period, that candidate shall be declared duly elected. 
(2) A person may, within seven days of a declaration made in accordance with clause (1), challenge the declaration, as prescribed.

(3) The processes specified in clauses (1) and (2) shall be completed at least thirty days before a general election.

Electoral code of conduct

Losing candidate not eligible for certain appointments

Election date for general elections

By-elections

Constituencies, wards and delimitation
54. A candidate and a political party shall comply with a prescribed electoral code of conduct.

55. A candidate who loses an election as a President, VicePresident, Member of Parliament or councillor is not eligible, during the term of that National Assembly or council, for appointment as-

(a) Minister; or

(b) Provincial Minister.

56. (1) A general election shall be held, every five years after the last general election, on the second Thursday of August.

(2) The day on which a general election is held shall be a public holiday.

57. (1) Where a vacancy occurs in the office of Member of Parliament, mayor, council chairperson or councillor, a by-election shall be held within ninety days of the occurrence of the vacancy.

(2) A by-election shall not be held within the one hundred-andeighty day period that precedes a general election.

(3) The Electoral Commission shall, by regulation, set the place where, and the date and time when, a by-election is to be held.

\section{Constituencies, Wards and Delimitation}

58. (1) Zambia shall be divided into constituencies and wards for purposes of elections to the National Assembly and councils, respectively.

(2) The number of constituencies shall be equal to the number of seats of elected members in the National Assembly.

(3) The number of wards in a district shall be prescribed.

(4) The Electoral Commission shall determine the names and boundaries of constituencies and wards. 
(5) The Electoral Commission shall, at intervals of not more than ten years, review the names and boundaries of constituencies and wards.

(6) The names and details of the boundaries of constituencies and wards shall be published in the Gazette and shall come into effect on the next dissolution of Parliament or councils.

(7) A person may apply to the Constitutional Court for review of a decision of the Electoral Commission made under this Article.

59. The Electoral Commission shall, in delimiting the boundaries of constituencies and wards-

(a) take into account the history, diversity and cohesiveness of the constituency or ward;

(b) have regard to population density, trends and projections;

(c) ensure that the number of inhabitants in each constituency or ward is reasonable, taking into account the means of communication and geographical features;

(d) ensure that constituencies and wards are wholly within districts; and

(e) seek to achieve an approximate equality of constituency and ward population, subject to the need to ensure adequate representation for urban and sparsely populated areas.

\section{Political Parties}

60. (1) A political party has the right to-

(a) disseminate information on social and economic programmes of a national character and of its political ideology;

(b) sponsor candidates for election or nomination to a State office in respect of which elections are required to be held; and

(c) conduct primary elections for the selection of candidates.

(2) A political party shall-

(a) promote the values and principles specified in this Constitution;

(b) have a national character;

(c) promote and uphold national unity;

Political parties
Matters to

take into

account

when

delimiting

constituencies

and wards

(n)


(d) promote and practice democracy through regular, free and fair elections within the party;

(e) respect the right of its members to participate in the affairs of the political party;

(f) respect the right of its members to seek redress from a court or tribunal when aggrieved by a decision of the political party; and

(g) subscribe to and observe the code of conduct for political parties, as prescribed.

(3)A political party shall not-

(a) be founded on a religious, linguistic, racial, ethnic, tribal, gender, sectoral or provincial basis or engage in propaganda based on any of these factors;

(b) engage in or encourage violence or intimidate its members, supporters, opponents or other persons;

(c) engage in corrupt practices; and

(d) except as prescribed, use public resources to promote its interest or that of its members.

(4) The following shall be prescribed with regard to political parties:

(a) the establishment and management of a Political Parties'

Fund to provide financial support to political parties with seats in the National Assembly;

(b) the accounts of political parties which are funded under the Political Parties' Fund and the submission of audited accounts by political parties;

(c) the sources of funds for political parties;

(d) the maximum amount of money to be used for campaigns during elections; and

(e) matters incidental to matters specified in this clause.

Renumbering and renaming of Part V
5. The Constitution is amended by the renumbering of Part $\mathrm{V}$ as Part VI, and the deletion of the heading to that Part and the substitution therefor of the following heading and sub-heading: 


\section{LEGISLATURE}

\section{Legislative Authority}

6. The Constitution is amended by the repeal of Articles 62 to 78 inclusive and the substitution therefor of the following:

61. The legislative authority of the Republic derives from the people of Zambia and shall be exercised in a manner that protects this Constitution and promotes the democratic governance of the Republic.

62. (1) There is established the Parliament of Zambia which consists of the President and the National Assembly.

(2) The legislative authority of the Republic is vested in and exercised by Parliament.

(3) A person or body, other than Parliament, shall not have power to enact legislation, except as conferred by this Constitution.

(4) A member of the National Assembly shall be referred to as a Member of Parliament.

63. (1) Parliament shall enact legislation through Bills passed by the National Assembly and assented to by the President.

(2) The National Assembly shall oversee the performance of Functions of Parliament and National Assembly executive functions by-

(a) ensuring equity in the distribution of national resources amongst the people of Zambia;

(b) appropriating funds for expenditure by State organs, State institutions, provincial administration, local authorities and other bodies;

(c) scrutinising public expenditure, including defence, constitutional and special expenditure;

(d) approving public debt before it is contracted; and

(e) approving international agreements and treaties before these are acceded to or ratified.

64. (1) A Member of Parliament or Minister may introduce a Bill in the National Assembly.

(2) The expenses of drafting and introducing a Bill in the National Introduction of Bills in

National

Assembly Assembly shall be a charge on the Consolidated Fund.

65. (1) A Money Bill shall be introduced by a Minister.

Money Bills 
(2) A Money Bill means a Bill that provides for, among other matters-

(a) the imposition, repeal, remission, alteration or regulation of taxes;

(b) the imposition of charges on the Consolidated Fund or any other public fund, or the variation or repeal of any of those charges;

(c) the appropriation, receipt, custody, investment, issue or audit of accounts of public monies;

(d) the grant of public money to a person or authority or the variation or revocation of such grant;

(e) the raising or guaranteeing of a loan or the repayment of it; or

(f) matters incidental to matters specified in this clause.

(3) A Bill that confers emoluments on State officers or Constitutional office holders shall only be introduced in the National Assembly if the emoluments are recommended by the Emoluments Commission.

Presidential assent and

66. (1) Where a Bill is presented to the President for assent, referral the President shall, within twenty-one days after receipt of the Bill-

(a) assent to the Bill; or

(b) refer the Bill to the National Assembly for reconsideration, indicating any reservation that the President has concerning the Bill.

(2) Where the President refers the Bill to the National Assembly for reconsideration, in accordance with clause (1) (b), the National Assembly may-

(a) amend the Bill taking into account the President's reservation; or

(b) pass the Bill, without amendment, by a vote supported by at least two-thirds of the Members of Parliament. 
(3) Where the National Assembly passes the Bill with amendments, in accordance with clause (2) (a), the Speaker shall submit the Bill to the President for assent.

(4) Where the National Assembly passes the Bill, in accordance with clause (2) (b) -

(a) the Speaker shall, within seven days of passing the Bill, resubmit the Bill to the President; and

(b) the President shall, within seven days of receipt of the Bill, assent to the Bill.

(5) Where the National Assembly fails to pass the Bill, in accordance with clause (2) (b), the Bill shall not be presented to the National Assembly in that session.

(6) Where the President does not assent to a Bill within the periods prescribed in clauses (1) and (4), the Bill shall be considered assented to upon the expiry of those periods.

67. (1) Article 62 or 63 shall not prevent Parliament from conferring on a person or authority power to make statutory instruments.

(2) A statutory instrument shall be published in the Gazette-

(a) not later than twenty-eight days after it is made; or

(b) in the case of a statutory instrument which will not have the force of law unless it is approved by a person or an authority, other than a person or an authority by which it was made, not later than twenty-eight days after it is so approved;

and if the statutory instrument is not so published, it is void from the date on which it was made.

(3) A person may challenge a statutory instrument, for its constitutionality, within fourteen days of the publication of the statutory instrument in the Gazette.

(4) Where the Constitutional Court considers that a challenge of a statutory instrument is frivolous or vexatious, the Constitutional Court shall dismiss the action.

(5) Where the Constitutional Court decides that a provision of a statutory instrument is inconsistent with a provision of this Constitution, that statutory instrument is void from the date on which it was made. 
(6) A Member of Parliament who intends to challenge a statutory instrument, on its constitutionality, shall follow the procedure laid down in the Standing Orders of the National Assembly.

Elections to National Assembly and Members of Parliament

Election and composition of National Assembly

Nominated Members of Parliament

Qualifications and

disqualifica-

tions of

Members of

Parliament
68. (1) A Member of Parliament shall be elected in accordance with Article 47 (2) and this Article.

(2) The National Assembly shall consist of-

(a) one hundred and fifty-six members directly elected on the basis of a simple majority vote under the first-pastthe-post system;

(b) not more than eight nominated members;

(c) the Vice-President;

(d) the Speaker; and

(e) the First and Second Deputy Speakers.

69. (1) The President may nominate a person referred to in Article 68 (2) (b) where the President considers it necessary to enhance the representation of special interests, skills or gender in the National Assembly.

(2) A person may be nominated as a Member of Parliament if the person qualifies to be elected as such under Article 70 .

(3) A person who was a candidate for election in the last preceding general election or a subsequent by-election is not eligible to be nominated as a Member of Parliament

70. (1) Subject to clause (2), a person is eligible to be elected as a Member of Parliament, if that person-

(a) is a citizen;

(b) is at least twenty-one years old;

(c) is a registered voter; 
(d) has obtained, as a minimum academic qualification, a grade twelve certificate or its equivalent; and

(e) declares that person's assets and liabilities, as prescribed.

(2) A person is disqualified from being elected as a Member of Parliament if that person-

(a) is validly nominated as a candidate in a presidential election;

(b) is a public officer or Constitutional office holder;

(c) is a judge or judicial officer;

(d) has a mental or physical disability that would make the person incapable of performing the legislative function;

(e) is an undischarged bankrupt;

(f) is serving a sentence of imprisonment for an offence under a written law;

( $g$ ) has, in the immediate preceding five years, served a term of imprisonment of at least three years;

(h) has, in the immediate preceding five years, been removed from public office on grounds of gross misconduct; or

(i) holds or is acting in an office, as prescribed, the functions of which involve or are connected with the conduct of elections.

71. Anomination for election to the National Assembly is valid if the candidate-

(a) has paid a prescribed election fee to the Electoral Commission; and

(b) is supported by at least fifteen persons registered as voters in the constituency in which the candidate is standing for election. 
Vacation of office as

Member of

Parliament

and

dissolution

of political

party
72. (1) A Member of Parliament shall, except the Speaker and the First Deputy Speaker, vacate the seat in the National Assembly upon a dissolution of Parliament.

(2) The office of Member of Parliament becomes vacant if the member-

(a) resigns by notice, in writing, to the Speaker;

(b) becomes disqualified for election in accordance with Article 70 ;

(c) acts contrary to a prescribed code of conduct;

(d) resigns from the political party which sponsored the member for election to the National Assembly;

(e) is expelled from the political party which sponsored the member for election to the National Assembly;

(f) ceases to be a citizen;

(g) having been elected to the National Assembly, as an independent candidate, joins a political party;

(h) is disqualified as a result of a decision of the Constitutional Court; or

(i) dies.

(3) The office of a nominated Member of Parliament becomes vacant if the member-

(a) resigns by notice, in writing, to the speaker;

(b) is disqualified under Article 70;

(c) acts contrary to a prescribed code of conduct;

(d) ceases to be a citizen;

(e) dies; or

(f) has the member's nomination revoked by the President. 
(4) A person who causes a vacancy in the National Assembly due to the reasons specified under clause (2) (a), (b), (c), (d), (g) and $(h)$ shall not, during the term of that Parliament-

(a) be eligible to contest an election; or

(b) hold public office.

(5) Where a Member of Parliament is expelled as provided in clause (2) (e), the member shall not lose the seat until the expulsion is confirmed by a court, except that where the member does not challenge the expulsion in court and the period prescribed for challenge lapses, the member shall vacate the seat in the National Assembly.

(6) Where a court determines that an expulsion of a member, as provided in clause (2) (e), was not justified, there shall be no byelection for that seat and the member shall opt to-

(a) remain a member of the political party and retain the seat; or

(b) resign from the political party and retain the seat as an independent member.

(7) Where a court determines that an expulsion of a member, as provided in clause (2) (e), was justified, the member shall vacate the seat in the National Assembly.

(8) Where a vacancy occurs in the National Assembly, the Speaker shall, within seven days of the occurrence of the vacancy, inform the Electoral Commission of the vacancy, in writing, and a by-election shall be held in accordance with Article 57.

(9) If a political party is dissolved, a Member of Parliament shall retain the member's seat as an independent member. 
Petition of election of Member of Parliament

Leader of Government Business and Leader of

Opposition

Sittings of National Assembly

Freedom of speech, powers, privileges and immunities
73. (1) A person may file an election petition with the High Court to challenge the election of a Member of Parliament.

(2) An election petition shall be heard within ninety days of the filing of the petition.

(3) A person may appeal against the decision of the High Court to the Constitutional Court.

(4) A Member of Parliament whose election is petitioned shall hold the seat in the National Assembly pending the determination of the election petition.

74. (1) The President shall appoint the Vice-President to be the Leader of Government Business in the National Assembly.

(2) The opposition political party with the largest number of seats in the National Assembly shall elect a Leader of the Opposition from amongst the Members of Parliament who are from the opposition.

\section{Proceedings of National Assembly}

75. (1) The Speaker shall, within thirty days after a general election, by notice in the Gazette, appoint a date for the first sitting of the National Assembly for that term.

(2) There shall be at least three sittings of the National Assembly in a session of Parliament which shall be held at such times and on such days as the Speaker appoints.

(3) Notwithstanding clause (2), the President, or two-thirds of the Members of Parliament, may, in writing, request the Speaker to summon a sitting of the National Assembly, as prescribed.

76. (1) A Member of Parliament has freedom of speech and debate in the National Assembly and that freedom shall not be ousted or questioned in a court or tribunal.

(2) A Member of Parliament shall have the powers, privileges and immunities, as prescribed. 
77. (1) Subject to this Article and Article 78, the National Assembly shall regulate its own procedure and make Standing Orders for the conduct of its business.

(2) The proceedings of the National Assembly shall not be invalid due to-

(a) a vacancy in its membership; or

(b) the presence or participation of a person not entitled to be present at, or to participate in, the proceedings of the National Assembly.

(3) There shall preside at a sitting of the National Assembly-

(a) the Speaker;

(b) in the absence of the Speaker, the First Deputy Speaker;

(c) in the absence of the First Deputy Speaker, the Second Deputy Speaker; or

(d) in the absence of the Second Deputy Speaker, another Member of Parliament as the members may elect for that sitting.

(4) The quorum for a meeting of the National Assembly shall be one-third of the Members of Parliament.

78. (1) Except as otherwise provided in this Constitution, a question proposed for decision in the National Assembly shall be determined by a majority of the Members of Parliament present and voting.

(2) On a question proposed for decision in the National Assembly -

(a) the Speaker shall have no vote; and

(b) in the case of a tie, the question shall be lost.

7. The Constitution is amended by the repeal of Articles 80 to 90 inclusive and the substitution therefor of the following:
Procedure of

National

Assembly 
Committees of National Assembly

Term and prorogation of Parliament
80. (1) The National Assembly may establish parliamentary committees.

(2) Parliamentary committees shall be established at the first sitting of the National Assembly after a general election and after the election of the Speaker and the Deputy Speakers.

(3) The National Assembly shall, in selecting members of a parliamentary committee, ensure that there is equitable representation of the political parties holding seats in the National Assembly and independent Members of Parliament.

(4) The Standing Orders shall provide for the categories, functions and procedures of parliamentary committees.

81. (1) The term of Parliament shall be five years commencing from the date that the Members of Parliament are sworn into office after a general election and ending on the date that Parliament is dissolved.

(2) The National Assembly may, when the Republic is at war, by resolution supported by a simple majority vote of the Members of Parliament, extend the term of Parliament for not more than twelve months at a time.

(3) Parliament shall stand dissolved ninety days before the holding of the next general election.

(4) Subject to clauses (5), (6) and (7), the President may dissolve Parliament if the Executive cannot effectively govern the Republic due to the failure of the National Assembly to objectively and reasonably carry out its legislative function.

(5) Where the President intends to dissolve Parliament in accordance with clause (4), the President shall inform the public and refer the matter, within seven days, to the Constitutional Court.

(6) The Constitutional Court shall hear the matter, referred to it in accordance with clause (5), within seven days of receipt of the matter. 
(7) The Constitutional Court shall, where it decides that the situation in clause (4) exists, inform the President and the President shall dissolve Parliament.

(8) Where Parliament is dissolved under clauses (3) and (4), the President shall, until the President-elect assumes office, continue to perform the executive functions, in accordance with Article 104.

(9) Where Parliament is dissolved under clauses (3) and (4), general elections shall be held within ninety days of the dissolution.

(10) The President may, due to a state of war, state of public emergency or threatened state of public emergency, after the dissolution of Parliament and before the holding of general elections, recall the National Assembly that was dissolved.

(11) The President may, in consultation with the Speaker, prorogue Parliament by proclamation.

\section{Speaker, Deputy Speakers and Officers of National Assembly}

82. (1) The Members of Parliament shall elect, by secret ballot, a Speaker of the National Assembly from a list of names of persons, who are qualified to be elected as Members of Parliament, but are not Members of Parliament, submitted to the National Assembly by-

(a) the President; and

(b) political parties holding seats in the National Assembly.

(2) A person is qualified to be elected as Speaker of the National Assembly if that person-

(a) is a citizen by birth or descent;

(b) does not have dual citizenship;

(c) has been ordinarily resident in Zambia;

(d) is at least thirty-five years old; 
(e) has obtained, as a minimum academic qualification, a grade twelve certificate or its equivalent;

(f) declares that person's assets and liabilities, as prescribed;

(g) has paid that person's taxes or made arrangements satisfactory to the appropriate tax authority for the payment of the taxes; and

(h) is not a Member of Parliament.

(3) There shall be two Deputy Speakers of the National Assembly who are not members of the same political party and of the same gender.

(4) The Members of Parliament shall elect, by secret ballot, the First Deputy Speaker from a list of three names, selected by the political parties represented in the National Assembly, from among persons who are qualified to be elected as Members of Parliament but are not Members of Parliament.

(5) The Members of Parliament shall elect, by secret ballot, the Second Deputy Speaker from among their number.

(6) The Members of Parliament shall elect a Speaker and the Deputy Speakers-

(a) when the National Assembly first sits after a general election; and

(b) if the office of Speaker or Deputy Speaker becomes vacant.

(7) The office of Speaker or Deputy Speaker shall become vacant if the Speaker or Deputy Speaker-

(a) becomes disqualified under Article 70 (2);

(b) resigns by notice, in writing, to the President;

(c) is removed from office in accordance with Article 83; or

(d) dies.

(8) When the office of Speaker or Deputy Speaker becomes vacant, business shall not be transacted in the National Assembly, other than an election to the office of Speaker or Deputy Speaker. 
83. (1) A Member of Parliament, supported by at least onethird of the Members of Parliament, may move a motion for the removal of the Speaker or a Deputy Speaker, alleging that the Speaker or Deputy Speaker has-

(a) violated this Constitution;

(b) a mental or physical disability that makes the Speaker or Deputy Speaker incapable of performing the functions of the office of Speaker or Deputy Speaker; or

(c) committed gross misconduct.

(2) The motion shall specify the particulars of the allegation.

(3) Where a motion is supported by a resolution of two-thirds of the Members of Parliament, the Speaker or Deputy Speaker shall be suspended from office and the National Assembly shall refer the matter to a parliamentary committee.

(4) The parliamentary committee, to which the matter has been referred in accordance with clause (3), shall, within seven days of the reference-

(a) investigate the matter, and the Speaker or Deputy Speaker has the right to appear, be heard and be represented before the parliamentary committee; and

(b) report to the National Assembly whether or not the particulars of the allegations specified in the motion have been substantiated.

(5) Where the parliamentary committee reports that the particulars of the allegation against the Speaker or Deputy Speaker-

(a) are not substantiated, the National Assembly shall, on a motion supported by the votes of not less than two-thirds of the Members of Parliament, taken by secret ballot, resolve that the Speaker or Deputy Speaker-

(i) did not commit the violations specified in the motion; and

(ii) be reinstated; or

(b) are substantiated, the National Assembly shall, on a motion supported by the votes of not less than two-thirds of the Members of Parliament, taken by secret ballot, resolve that the Speaker or Deputy Speaker has committed the violations specified in the motion and that the Speaker or Deputy Speaker cease to hold office forthwith.

Removal of Speaker on specified grounds 
(6) Where a resolution is made, in accordance with clause (5) (b), an election of Speaker or Deputy Speaker shall be conducted within seven days of the resolution, in accordance with Article 82.

Clerk of National Assembly

Officers of National Assembly

Presidential address to

National

Assembly and presidential messages

Vote of censure
84. (1) There shall be a Clerk of the National Assembly who shall be appointed by the Parliamentary Service Commission, subject to ratification by the National Assembly.

(2) A person shall not be appointed Clerk of the National Assembly unless that person has the academic qualifications, experience and skills prescribed.

(3) Subject to clause (5), the Clerk of the National Assembly shall retire on attaining the age of sixty-five years.

(4) The Clerk of the National Assembly may retire, with full benefits, on attaining the age of sixty years.

(5) The National Assembly may, by a resolution supported by the votes of not less than two-thirds of the Members of Parliament, remove the Clerk of the National Assembly on the same grounds and procedure that apply to the removal of a judge.

(6) The Clerk of the National Assembly may resign from office by three months' notice, in writing, to the Speaker.

85. There shall be appointed such officers in the department of the Clerk of the National Assembly, as prescribed.

\section{General Parliamentary Matters}

86. (1) The President shall, at least twice in every year, attend and address the National Assembly.

(2) The President may, at any time during the term of Parliament, send a message to the National Assembly which shall be read by the Leader of Government Business or by a Minister designated by the President.

87. (1) The National Assembly may censure a Minister or Provincial Minister where the Members of Parliament are dissatisfied with the conduct or performance of the Minister or Provincial Minister.

(2) The proceedings to censure a Minister or Provincial Minister shall be commenced by a notice of motion, submitted to the Speaker, signed by at least one-third of the Members of Parliament, stating the grounds in support of the motion. 
(3) The Speaker shall, on receipt of the notice of motion submitted in accordance with clause (2), cause a copy of the notice of motion to be given to the Minister or Provincial Minister.

(4) The notice of motion to censure a Minister or Provincial Minister shall not be debated until after the expiry of seven days from the date the notice of motion is submitted to the Speaker.

(5) The National Assembly may pass a vote of censure on a Minister or Provincial Minister by resolution supported by twothirds of the votes of the Members of Parliament.

88. (1) A citizen may petition the National Assembly to initiate the enactment, amendment or repeal of legislation.

(2) A citizen may comment on a deliberation, statement or decision of the National Assembly.

(3) The manner of petitioning and commenting referred to in this Article shall be prescribed.

89. (1) The National Assembly shall facilitate public involvement in the legislative process.

(2) The National Assembly or a parliamentary committee shall not exclude the public or media from its sittings, unless there are justifiable reasons for the exclusion and the Speaker informs the public or media of the reasons.

8. The Constitution is amended by the repeal of Parts VI to XIV inclusive and the substitution therefor of the following:

\section{PART VII}

EXECUTIVE

\section{Executive Authority}

90. The Executive authority derives from the people of Zambia and shall be exercised in a manner compatible with the principles of social justice and for the people's well-being and benefit.

91. (1) There shall be a President of the Republic who shall be the Head of State and Government and Commander-in-Chief of the Defence Force.

Public access and participation

Repeal and replacement of Parts VI to XIV

Principles of executive authority

(2) The executive authority of the State vests in the President and, subject to this Constitution, shall be exercised directly by the President or through public officers or other persons appointed by the President. 
(3) The President shall, in exercise of the executive authority of the State-

(a) respect, uphold and safeguard this Constitution;

(b) safeguard the sovereignty of the Republic;

(c) promote democracy and enhance the unity of the Nation;

(d) respect the diversity of the different communities of Zambia;

(e) promote and protect the rights and freedoms of a person; and

(f) uphold the rule of law.

Executive functions of President
92. (1) The President shall perform, with dignity, leadership and integrity, the acts that are necessary and expedient for, or reasonably incidental to, the exercise of the executive authority.

(2) Without limiting the other provisions of this Constitution, the President shall-

(a) appoint ambassadors, high commissioners, plenipotentiaries, diplomatic representatives and consuls;

(b) receive and accredit foreign ambassadors, high commissioners, plenipotentiaries, diplomatic representatives, consuls and heads of international organisations;

(c) negotiate and sign international agreements and treaties and, subject to the approval of the National Assembly, ratify or accede to international agreements and treaties;

(d) establish, merge and dissolve Government ministries, subject to the approval of the National Assembly;

(e) appoint persons as are required by this Constitution or any other law to be appointed by the President;

(f) appoint persons as are required to perform special duties for the Executive;

(g) confer honours;

(h) sign and promulgate proclamations as specified in this Constitution or as prescribed;

(i) initiate Bills for submission to, and consideration by, the National Assembly; and 
(j) perform other functions specified by this Constitution or as prescribed.

93. (1) A decision or instruction of the President shall be in writing under the President's signature.

(2) The signature of the President on an instrument shall be under Public Seal.

94. (1) Where the performance of an executive function is expressed by this Constitution to be subject to approval by the National Assembly, the National Assembly shall, in the sitting next after receipt of the request for approval, give the approval within twenty-one days of the commencement of the sitting.

(2) Where an approval is not given within the period specified in clause (1) or the National Assembly unreasonably refuses to give an approval as requested, the President shall refer the matter to the Constitutional Court for hearing and the decision of the Constitutional Court is final.

(3) Where the Constitutional Court decides that the refusal or delay by the National Assembly was justified, the President shall comply with the order of the Court.

(4) Where the Constitutional Court decides that the refusal or delay by the National Assembly was unreasonable, the National Assembly shall proceed to approve the matter.

95. (1) Where in this Constitution an appointment to an office or the taking of a measure by the President is subject to ratification by the National Assembly, the National Assembly shall, in the sitting next after receipt of the request for ratification, give its ratification within twenty-one days of the commencement of the sitting.

(2) Where ratification is not given within the period specified in clause (1), the President shall propose another measure or appoint another person to that office and submit that measure or appointment for ratification by the National Assembly.

(3) Where the National Assembly refuses or delays the ratification for the second time, the President shall propose another measure or appoint another person to that office and shall submit that measure or appointment for ratification by the National Assembly.

(4) Where the National Assembly refuses or delays the ratification of the measure or appointment for the third time, that measure or appointment shall take effect.

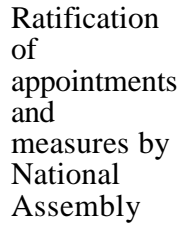

Assembly

Confirmation of presidential decisions and instructions

Approval of appointments and measures by National Assembly 
Advisory Committee on prerogative of mercy

Prerogative of mercy

Protection of President from legal proceedings
96. (1) There shall be an Advisory Committee on the prerogative of mercy which shall consist of persons appointed by the President.

(2) The Advisory Committee shall advise the President on an action or a decision to be taken in relation to a person convicted of an offence by a court or court-martial.

(3) A member of the Advisory Committee shall hold office at the pleasure of the President.

(4) The President may preside at a meeting of the Advisory Committee.

(5) The Advisory Committee shall determine its own procedure for meetings.

97. (1) The President may, on the advice of the Advisory Committee-

(a) conditionally or unconditionally, pardon a person convicted of an offence;

(b) substitute a less severe form of punishment imposed on a person by a court; or

(c) remit the whole or part of a fine, penalty or forfeiture.

(2) A person who is sentenced to death may request the President, either directly or through a representative, for a pardon or commutation of the sentence.

98. (1) A person shall not institute or continue civil proceedings against the President or a person performing executive functions, as provided in Article 109, in respect of anything done or omitted to be done by the President or that person in their private capacity during the tenure of office as President.

(2) The President shall not, in the President's private capacity during the tenure of office as President, institute or continue civil proceedings against a person.

(3) For purposes of clauses (1) and (2), where a law limits the time within which proceedings may be brought against a person, the term of office shall not be taken into account in calculating the period of time.

(4) Subject to clause (9), the President or a person performing executive functions, as provided in Article 109, is immune from criminal proceedings which immunity continues after that person ceases to hold or perform the functions of that office. 
(5) Where there is prima facie evidence that a person who held the office of President or who performed executive functions committed an offence whilst in office or during the period that person performed executive functions, the President shall submit a report, outlining the grounds relating to the offence allegedly committed, to the National Assembly, requesting the National Assembly to remove the immunity from criminal proceedings of that person.

(6) Where the National Assembly receives a report, submitted in accordance with clause (5), the National Assembly shall constitute a select committee to scrutinise the grounds submitted and determine whether or not there is a prima facie case, based on the grounds submitted, that warrants the removal of the immunity from criminal proceedings, and recommend its decision to the National Assembly.

(7) The person who held the office of President or who performed executive functions has the right to appear, be represented and be heard before the select committee constituted under clause (6).

(8) Where the select committee, constituted under clause (6), recommends the removal of immunity from criminal proceedings from the person who held the office of President or who performed executive functions, the National Assembly may remove the immunity in respect of the alleged offence, by a resolution supported by a vote of not less than two-thirds of the Members of Parliament.

(9) Where immunity is removed, in accordance with clause (8), the person who held the office of President or who performed executive functions, shall be charged with the offence for which the immunity from criminal proceedings was removed.

(10) Where a court acquits the person who held the office of President or who performed executive functions, of an offence for which that person's immunity from criminal proceedings was removed, the immunity of that person shall, for all purposes, be deemed not to have been removed, without further proceedings.

(11) The process for the removal of immunity, provided for under this Article, shall not apply to an impeachable offence under Article108. 


\section{Election of President}

Returning officer for presidential elections

Qualifications and

disqualifications for

nomination as

presidential candidate
99. The Chairperson of the Electoral Commission shall be the Returning Officer in an election to the office of President.

100. (1) A person qualifies to be nominated as a candidate for election as President if that person-

(a) is a citizen by birth or descent;

(b) has been ordinarily resident in Zambia;

(c) is at least thirty-five years old;

(d) is a registered voter;

(e) has obtained, as a minimum academic qualification, a grade twelve certificate or its equivalent;

( $f$ ) is fluent in the official language;

(g) has paid that person's taxes or has made arrangements, satisfactory to the appropriate tax authority, for the payment of the taxes;

(h) declares that person's assets and liabilities, as prescribed;

(i) pays the prescribed election fee on, or before, the date fixed for the delivery of nomination papers; and

(j) is supported by at least one hundred registered voters from each Province.

(2) A person is disqualified from being nominated as a candidate for election as President if that person-

(a) is a public officer;

(b) has dual citizenship;

(c) is holding or acting in a Constitutional office or other public office;

(d) is a judge or judicial officer;

(e) was removed from public office on grounds of gross misconduct in the immediate preceding five years;

(f) has a mental or physical disability that would make the person incapable of performing the executive functions;

(g) is an undischarged bankrupt;

(h) is serving a sentence of imprisonment; or

(i) has, in the immediate preceding five years, served a term of imprisonment of at least three years. 
101. (1) A President shall be elected by registered voters in accordance with Article 47 (1) and this Article.

(2) The Returning Officer shall declare the presidential candidate who receives more than fifty percent of the valid votes cast during the election as President-elect.

(3) If at the initial ballot a presidential candidate does not receive more than fifty percent of the valid votes cast, a second ballot shall be held within thirty-seven days of the initial ballot, where the only candidates shall be the presidential candidates who obtained-

(a) the highest and second highest number of valid votes cast in the initial ballot; or

(b) an equal number of the valid votes cast in the initial ballot, being the highest votes amongst the presidential candidates that stood for election to the office of President.

(4) A person may within seven days of the declaration made under clause (2), petition the Constitutional Court to nullify the election of a presidential candidate who took part in the initial ballot on the ground that-

(a) the person was not validly elected; or

(b) a provision of this Constitution or other law relating to presidential elections was not complied with.

(5) The Constitutional Court shall hear an election petition filed in accordance with clause (4) within fourteen days of the filing of the petition.

(6) The Constitutional Court may, after hearing an election petition-

(a) declare the election of the presidential candidate valid;

(b) nullify the election of the presidential candidate; or

(c) disqualify the presidential candidate from being a candidate in the second ballot.

(7) A decision of the Constitutional Court made in accordance with clause (6) is final.

(8) The presidential candidate who obtains the majority of the valid votes cast in the second ballot shall be declared Presidentelect. 
Disqualification for run-off

Election petition
102. (1) If a presidential candidate-

(a) resigns for a reason other than health;

(b) becomes disqualified as specified in Article 100; or

(c) is disqualified by a decision of the Constitutional Court in accordance with Article 101;

the presidential candidate shall not take part in the second ballot and the candidate who scored the third highest number of valid votes cast in the initial ballot shall be a presidential candidate in the second ballot, together with the remaining presidential candidate that had initially qualified for the second ballot.

(2) If a presidential candidate-

(a) dies; or

(b) resigns due to ill-health;

before the taking of a second ballot, the running mate to that presidential candidate in the initial ballot shall assume the place of that presidential candidate.

(3) The presidential candidate who assumed the place of the previous presidential candidate in accordance with clause (2) shall appoint a running mate.

(4) Where both presidential candidates-

(a) resign;

(b) become disqualified under Article 100;

(c) become disqualified by a decision of the Constitutional Court under Article 101; or

(d) die;

before the taking of the second ballot, fresh nominations shall be filed with the Electoral Commission, as prescribed.

103. (1) A person may, within seven days of the declaration of a President-elect, petition the Constitutional Court to nullify the election of the President-elect on the ground that-

(a) the person was not validly elected; or

(b) a provision of this Constitution or other law relating to presidential elections was not complied with.

(2) The Constitutional Court shall hear an election petition relating to the President-elect within fourteen days of the filing of the petition. 
(3) The Constitutional Court may, after hearing an election petition-

(a) declare the election of the President-elect valid; or

(b) nullify the election of the President-elect and VicePresident-elect.

(4) A decision of the Constitutional Court under clause (3) is final.

(5) Where the election of the President-elect and VicePresident-elect is nullified by the Constitutional Court, a presidential election shall be held within thirty days from the date of the nullification.

104. (1) The President-elect shall be sworn into office and assume office in accordance with Article 105.

(2) Subject to clauses (3) and (4), where the Returning Officer declares a presidential candidate as President-elect, the incumbent shall continue to perform the executive functions until the Presidentelect assumes office, except the power to-

(a) make an appointment; or

(b) dissolve the National Assembly.

(3) Where an election petition is filed against the incumbent, under Article 103 (1), or an election is nullified, under Article 103(3) (b), the Speaker shall perform the executive functions, except the power to-

(a) make an appointment; or

(b) dissolve the National Assembly.

(4) Subject to Article 105 and except where the incumbent is the President-elect, the incumbent President shall, on the assumption of office by the President-elect, begin and complete the procedural and administrative handing over of the executive functions, to the President-elect, within fourteen days from the day the Presidentelect assumes office.

\section{Assumption of Office, Tenure of Office and Vacancy}

105. (1) The President-elect shall assume office after being sworn in by the Chief Justice or, in the absence of the Chief Justice, of office the Deputy Chief Justice.

(2) The President-elect shall be sworn into office on the Tuesday following- 
(a) the seventh day after the date of the declaration of the presidential election results, if no petition has been filed in accordance with Article 103; or

(b) the seventh day after the date on which the Constitutional Court declares the election to be valid.

(3) Subject to clause (4), where the President-elect dies, resigns or is for a reason unable to assume office, the Vice-Presidentelect shall be sworn into, and assume the office of President, in accordance with clause (1).

(4) Subject to clause (5), where the inability of the Presidentelect to assume office is as a result of an event or circumstance beyond the control of the President-elect, the Vice-President-elect shall not be sworn into office.

(5) A political party whose presidential candidate was declared President-elect or another person shall, within three days from the date on which the President-elect should have been sworn into office, petition the Constitutional Court to determine whether or not the inability of the President-elect to assume office is permanent.

(6) Where the Constitutional Court decides that the inability of the President-elect to assume office is permanent, the VicePresident-elect shall be sworn into office as President and assume office in accordance with clause (1).

(7) The Vice-President-elect who assumes office as President, in accordance with clause (3) or (6), shall appoint a person as Vice-President, subject to approval by the National Assembly, signified by a vote of not less than two-thirds of the Members of Parliament.

(8) Where the Vice-President elect who is supposed to assume the office of President as specified in clause (3) or (6) dies, resigns or is for another reason unable to assume the office of President-

(a) the Speaker shall perform the executive functions; and

(b) a presidential election shall be held within sixty days of the occurrence of the vacancy.

(9) The Speaker shall, perform the executive functions assumed in accordance with clause (8) except the power to make an appointment or dissolve the National Assembly.

(10) The Speaker shall, when the President-elect assumes office, complete the procedural and administrative handing over process within thirty days. 
106. (1) The term of office for a President is five years which shall run concurrently with the term of Parliament, except that the term of office of President shall expire when the President-elect assumes office in accordance with Article 105.

(2) A President shall hold office from the date the Presidentelect is sworn into office and ending on the date the next Presidentelect is sworn into office.

(3) A person who has twice held office as President is not eligible for election as President.

(4) The office of President becomes vacant if the President(a) dies;

(b) resigns by notice in writing to the Speaker of the National Assembly; or

(c) otherwise ceases to hold office under Article 81,107 or 108.

(5) When a vacancy occurs in the office of President, except under Article 81-

(a) the Vice-President shall immediately assume the office of President; or

(b) if the Vice-President is unable for a reason to assume the office of President, the Speaker shall perform the executive functions, except the power to-

(i) make an appointment; or

(ii) dissolve the National Assembly;

and a presidential election shall be held within sixty days after the occurrence of the vacancy.

(6) If the Vice-President assumes the office of President, in accordance with clause (5)(a), or a person is elected to the office of President as a result of an election held in accordance with clause 5(b), the Vice-President or the President-elect shall serve for the unexpired term of office and be deemed, for the purposes of clause (3)-

(a) to have served a full term as President if, at the date on which the President assumed office, at least three years remain before the date of the next general election; or

(b) not to have served a term of office as President if, at the date on which the President assumed office, less than three years remain before the date of the next general election.

Tenure of office of President and vacancy 
Removal of President on grounds of incapacity
107. (1) A Member of Parliament, supported by at least onethird of the Members of Parliament, may move a motion for the investigation of the physical or mental capacity of the President to perform executive functions.

(2) The motion moved in accordance with clause (1) shall specify the particulars of the allegation.

(3) Where the motion is supported in the National Assembly by a resolution of two-thirds of the Members of Parliament-

(a) the Speaker shall, within forty-eight hours of the adoption of the resolution, inform the Chief Justice of the resolution; and

(b) the Chief Justice shall immediately inform the President of the resolution, whereupon the President shall cease to perform the executive functions and the VicePresident shall perform the executive functions, except the power to-

(i) make an appointment; or

(ii) dissolve the National Assembly.

(4) The Chief Justice shall, within seven days of being informed of the resolution of the National Assembly, constitute a medical board, in consultation with the body responsible for regulating health practitioners, to inquire into the physical or mental capacity of the President.

(5) A medical board shall consist of not less than three persons selected from among persons who are registered as health practitioners.

(6) A medical board, constituted under clause (5), shall examine the President and report to the Chief Justice, within fourteen days of the constitution of the medical board, whether or not the President is capable of performing the executive functions.

(7) Where the medical board reports that the President is capable of performing the executive functions, the Chief Justice shall, within forty-eight hours of the receipt of the medical report, cause a copy of the report to be presented to the National Assembly which shall resolve that the President should resume performing the executive functions. 
(8) Where the medical board reports that the President is not capable of performing the executive functions, the Chief Justice shall, within forty-eight hours of the receipt of the medical report, cause a copy of the report to be presented to the National Assembly which shall resolve that the President should cease to hold office and the Vice-President shall assume the office of President in accordance with Article 106 (5).

(9) This Article applies to the Vice-President.

108. (1) A Member of Parliament, supported by at least onethird of the Members of Parliament, may move a motion for the Impeachment of President impeachment of the President alleging that the President has committed-

(a) a violation of a provision of this Constitution or other law;

(b) a crime under international law; or

(c) gross misconduct.

(2) The motion, moved in accordance with clause (1), shall specify the particulars of the allegation.

(3) Where a motion, moved in accordance with clause (1), is supported, in the National Assembly, by a resolution of two-thirds of the Members of Parliament-

(a) the Speaker shall, within forty-eight hours of the adoption of the resolution, inform the Chief Justice of the resolution; and

(b) the Chief Justice shall immediately inform the President of the resolution, whereupon the President shall cease to perform the executive functions and the VicePresident shall perform the executive functions, except the power to-

(i) make an appointment; or

(ii) dissolve the National Assembly.

(4) The Chief Justice shall, within seven days of being informed of the resolution of the National Assembly, appoint a tribunal, in consultation with the Judicial Service Commission, which shall consist of a chairperson and not less than two other members from among persons who hold, have held or qualify to hold, the office of judge.

(5) The tribunal appointed under clause (4) shall, within thirty days of its appointment- 
(a) investigate the matter relating to the impeachment of the President; and

(b) report to the Chief Justice as to whether or not the particulars of the allegations specified in the motion have been substantiated.

(6) The President has the right to appear and be represented before the tribunal during its investigation.

(7) The Chief Justice shall, on receipt of the report referred to in clause (5) (b), immediately submit the report to the National Assembly.

(8) Where the tribunal reports that the particulars of an allegation against the President-

(a) is not substantiated, the National Assembly shall, on a motion supported by the votes of not less than two-thirds of the Members of Parliament, taken by secret ballot, resolve that-

(i) the President did not commit the violations specified in the motion; and

(ii) further proceedings shall not be taken with respect to the allegation; or

(b) is substantiated, the National Assembly shall, on a motion supported by the votes of not less than two-thirds of the Members of Parliament, taken by secret ballot, resolve that the President has committed the violations specified in the motion and that the President should cease to hold office forthwith.

(9) The President shall, on the passing of a resolution in accordance with-

(a) clause (7) (a), resume to perform the executive functions; or

(b) clause (7) (b), cease to hold office and be amenable to prosecution without the need to lift the immunity under Article 98.

(10) Where a motion is moved in accordance with clause (1), the President shall not dissolve Parliament.

(11) This Article applies to the Vice-President. 
109. (1) If the President leaves Zambia or is absent from office, the Vice-President shall perform the executive functions specified, in writing, by the President until the President returns to office or revokes the authority. of executive functions during absence of

(2) Where the Vice-President is incapable of performing the executive functions, as specified under clause (1), the President shall appoint a member of the Cabinet to perform the executive functions until the-

(a) Vice-President is able to perform those functions;

(b) President returns to office; or

(c) President revokes the authority.

(3) Where the President is unable to appoint a member of Cabinet to perform the executive functions, in accordance with clause (2), Cabinet may elect one of its members to perform the executive functions until the-

(a) Vice-President is able to perform those functions;

(b) President returns to office; or

(c) President revokes the authority.

\section{Vice-President}

110. (1) There shall be a Vice-President for the Republic who shall be the running mate to a presidential candidate in a presidential election.

(2) The qualifications and disqualifications applying to a presidential candidate apply to the person selected by the presidential candidate to be the running mate.

(3) An election to the office of Vice-President shall be conducted at the same time as that of an election to the office of President so that a vote cast for a presidential candidate is a vote cast for the running mate, and if the presidential candidate is elected, the running mate shall be considered to have been elected.

(4) A Vice-President-elect shall be sworn into office by the Chief Justice or, in the absence of the Chief Justice, the Deputy Chief Justice.

(5) The Vice-President shall assume office on the same day that the President assumes office. 
Tenure of office of

Vice-

President and vacancy

111. (1) The term of office for a Vice-President is five years.

(2) A Vice-President shall hold office from the date the VicePresident-elect is sworn into office and ending on the date the next President-elect is sworn into office.

(3) A person who has twice held the office of Vice-President shall not be selected as a running mate.

(4) The office of Vice-President becomes vacant if the VicePresident-

(a) dies;

(b) resigns by notice in writing to the President;

(c) otherwise ceases to hold office under Article 81,107 or 108; or

(d) assumes the office of President.

(5) Where a vacancy occurs in the office of Vice-President, except as provided under Article 81, the President shall appoint another person to be Vice-President and the National Assembly shall, by a resolution supported by the votes of not less than twothirds of the Members of Parliament, approve the appointment of that person as Vice-President.

(6) The person who assumes office as Vice-President, in accordance with clause (5), shall serve for the unexpired term of office and be deemed for the purposes of clause (3) -

(a) to have served a full term as Vice-President if, at the date on which the Vice-President assumed office, more than three years remain before the date of the next general election; or

(b) not to have served a term of office as Vice-President if, at the date on which the Vice-President assumed office, less than three years remain before the date of the next general elections.

Functions of VicePresident
112. (1) The Vice-President shall be answerable to the President in the performance of the functions of Vice-President.

(2) The Vice-President shall-

(a) perform the functions that are assigned to the VicePresident by the President; 
(b) perform the executive functions during the periods specified in this Constitution; and

(c) assume the office of President as specified in Article 106 (5).

\section{Cabinet Ministers}

113. There shall be a Cabinet consisting of the-

Cabinet
(a) President;
(b) Vice-President;
(c) Ministers; and
(d) Attorney-General, as ex-officio member.

114. (1) The functions of Cabinet are as follows:

(a) approve and cause to be implemented Government policy;

(b) approve Government Bills for introduction to the National Assembly;

(c) approve and cause the national budget to be presented to the National Assembly;

(d) recommend the accession and ratification of international agreements and treaties to the National Assembly;

(e) recommend, for approval of the National Assembly-

(i) loans to be contracted by the State; and

(ii) guarantees on loans contracted by State institutions or other institutions; and

( $f$ ) advise the President on matters relating to the performance of executive functions.

(2) Cabinet shall take collective responsibility for Cabinet decisions.

115. (1) Subject to this Article, Cabinet shall regulate its own procedure.

(2) Cabinet shall meet at least once in every month to perform Proceedings of Cabinet meetings its functions as specified in Article 114.

(3) The Secretary to the Cabinet shall, in consultation with the President, call for meetings of Cabinet.

(4) There shall preside at meetings of Cabinet-

(a) the President;

(b) in the absence of the President, the Vice-President; or 
(c) in the absence of the Vice-President, a member of Cabinet appointed by the President.

(5) Where the President is unable to appoint a member of Cabinet to preside at a meeting of Cabinet, the members of Cabinet present at the meeting may elect one of the members to preside.

(6) The President may, in consultation with the Secretary to the Cabinet, invite a person whose presence is desirable to attend and participate in the deliberations of a meeting of Cabinet but that person shall have no vote.

Ministers

116. (1) The President shall appoint a prescribed number of Members of Parliament as Ministers.

(2) A Minister shall be responsible, under the direction of the President, for the policy and strategic direction of a Ministry, department or other State institution, as assigned by the President.

(3) The office of Minister becomes vacant if-

(a) the Minister is removed from office by the President;

(b) the Minister resigns, by notice in writing to the President;

(c) in the case of a nominated Member of Parliament, the nomination is revoked;

(d) the Minister dies;

(e) another person assumes the office of President; or

(f) the Minister has a mental or physical disability that makes the Minister incapable of performing the functions of that office.

Provincial

Minister

117. (1) The President shall appoint a Provincial Minister for each Province from among Members of Parliament.

(2) The office of Provincial Minister becomes vacant if-

(a) the Provincial Minister is removed from office by the President;

(b) the Provincial Minister resigns, by notice in writing to the President;

(c) the Provincial Minister dies;

(d) another person assumes the office of President;

(e) the Provincial Minister has a mental or physical disability that makes the Provincial Minister incapable of performing the functions of that office; or 
( $f$ ) in the case of a nominated Member of Parliament, the nomination is revoked.

(3) A Provincial Minister shall-

(a) be the head of Government in the Province;

(b) ensure that national policies are implemented in all districts in the Province; and

(c) ensure that the concurrent functions of the Province and the exclusive functions of the local authorities are performed in accordance with this Constitution and other laws.

\section{PART VIII}

JUDICIARY

\section{Judicial Authority, System of Courts and Independence}

118. (1) The judicial authority of the Republic derives from the people of Zambia and shall be exercised in a just manner and such exercise shall promote accountability.

(2) In exercising judicial authority, the courts shall be guided by the following principles:

(a) justice shall be done to all, without discrimination;

(b) justice shall not be delayed;

(c) adequate compensation shall be awarded, where payable;

(d) alternative forms of dispute resolution, including traditional dispute resolution mechanisms, shall be promoted, subject to clause (3);

(e) justice shall be administered without undue regard to procedural technicalities; and

(f) the values and principles of this Constitution shall be protected and promoted.

(3) Traditional dispute resolution mechanisms shall not-

(a) contravene the Bill of Rights;

(b) be inconsistent with other provisions of this Constitution or other written law; or

(c) be repugnant to justice and morality.

119. (1) Judicial authority vests in the courts and shall be exercised by the courts in accordance with this Constitution and other laws.

(2) The courts shall perform the following judicial functions:

Principles of judicial authority
Vesting of judicial authority and performance of judicial function 
(a) hear civil and criminal matters; and

(b) hear matters relating to, and in respect of, this Constitution.

(3) Except as otherwise provided in this Constitution, other law or as ordered by a court, the proceedings of a court shall be in public.

System of court

Ranking of

Supreme and

Constitutional

Courts

Functional independence of Judiciary
120. (1) The Judiciary shall consist of the superior courts and the following courts:

(a) subordinate courts;

(b) small claims courts;

(c) local courts; and

(d) courts, as prescribed.

(2) The courts shall be courts of record, except that local courts shall progressively become courts of record.

(3) The following matters shall be prescribed:

(a) processes and procedures of the courts;

(b) jurisdiction, powers and sittings, of the Industrial Relations Court, Commercial Court, Family Court, Children’s Court and other specialised courts;

(c) classification and divisions of the subordinate courts;

(d) classification and divisions of the local courts;

(e) jurisdiction and composition of subordinate courts, small claims courts, local courts and other prescribed courts; and

(f) grading of judicial officers and staff of subordinate courts, local courts and other prescribed courts.

(4) The courts, except the Supreme Court and the Constitutional Court, shall be devolved to the Province and progressively to districts.

(5) Superior courts shall sit as circuit courts in districts, in accordance with a circuit schedule issued by the Chief Justice.

121. The Supreme Court and Constitutional Court rank equivalently.

122. (1) In the exercise of the judicial authority, the Judiciary shall be subject only to this Constitution and the law and not be subject to the control or direction of a person or an authority. 
(2) A person and a person holding a public office shall not interfere with the performance of a judicial function by a judge or judicial officer.

(3) The Judiciary shall not, in the performance of its administrative functions and management of its financial affairs, be subject to the control or direction of a person or an authority.

(4) A person and a person holding a public office shall protect the independence, dignity and effectiveness of the Judiciary.

(5) The office of a judge or judicial officer shall not be abolished while there is a substantive holder of the office.

123. (1) The Judiciary shall be a self-accounting institution and shall deal directly with the Ministry responsible for finance in matters relating to its finances.

Financial independence of Judiciary

(2) The Judiciary shall be adequately funded in a financial year to enable it effectively carry out its functions.

\section{Establishment, Jurisdiction and sittings of Superior Courts}

124. There is established the Supreme Court which consists of-

(a) the Chief Justice;

(b) the Deputy Chief Justice; and

(c) eleven other judges or a higher number of judges, as prescribed.

125. (1) Subject to Article 128, the Supreme Court is the final court of appeal.

(2) The Supreme Court has-

(a) appellate jurisdiction to hear appeals from the Court of Appeal; and

(b) jurisdiction conferred on it by other laws.

(3) The Supreme Court is bound by its decisions, except in the interest of justice and development of jurisprudence.

126. (1) The Supreme Court shall be constituted by an uneven number of not less than three judges, except when hearing an interlocutory matter.

(2) The Supreme Court shall be constituted by one judge when hearing an interlocutory matter.
Establishment and composition of Supreme

Court

Jurisdiction of Supreme Court

Sittings of Supreme Court 
(3) The full bench of the Supreme Court shall be constituted by an uneven number of not less than five judges.

(4) The Supreme Court shall be presided over by-

(a) the Chief Justice;

(b) in the absence of the Chief Justice, the Deputy Chief Justice; and

(c) in the absence of the Deputy Chief Justice, the most senior judge of the Supreme Court, as constituted.

Establishment and

composition

of

Constitutional Court

Jurisdiction of

Constitutional Court
127. There is established the Constitutional Court which consists of-

(a) the President of the Constitutional Court;

(b) the Deputy President of the Constitutional Court; and

(c) eleven other judges or a higher number of judges, as prescribed.

128. (1) Subject to Article 28, the Constitutional Court has original and final jurisdiction to hear-

(a) a matter relating to the interpretation of this Constitution;

(b) a matter relating to a violation or contravention of this Constitution;

(c) a matter relating to the President, Vice-President or an election of a President;

(d) appeals relating to election of Members of Parliament and councillors; and

(e) whether or not a matter falls within the jurisdiction of the Constitutional Court.

(2) Subject to Article 28 (2), where a question relating to this Constitution arises in a court, the person presiding in that court shall refer the question to the Constitutional Court.

(3) Subject to Article 28, a person who alleges that-

(a) an Act of Parliament or statutory instrument;

(b) an action, measure or decision taken under law; or 
(c) an act, omission, measure or decision by a person or an authority;

contravenes this Constitution, may petition the Constitutional Court for redress.

(4) A decision of the Constitutional Court is not appealable to the Supreme Court.

129. (1) The Constitutional Court shall be constituted by an uneven number of not less than three judges, except when hearing an interlocutory matter.

(2) The Constitutional Court shall be constituted by one judge when hearing an interlocutory matter.

(3) The full bench of the Constitutional Court shall be constituted by an uneven number of not less than five judges.

(4) The Constitutional Court shall be presided over by-

(a) the President of the Constitutional Court;

(b) in the absence of the President of the Constitutional Court, the Deputy-President of the Constitutional Court; and

(c) in the absence of the Deputy-President of the Constitutional Court, the most senior judge of the Constitutional Court, as constituted.

130. There is established the Court of Appeal which consists of such number of judges as prescribed.

131. (1) The Court of Appeal has jurisdiction to hear appeals from-

(a) the High Court;

(b) other courts, except for matters under the exclusive jurisdiction of the Constitutional Court; and

(c) quasi-judicial bodies, except a local government elections tribunal.

(2) An appeal from a decision of the Court of Appeal shall be made to the Supreme Court with leave of the Court of Appeal.

132. (1) The Court of Appeal shall be constituted by an uneven number of not less than three judges, except when hearing an appeal in an interlocutory matter.

Establishment and composition of Court of Appeal

Jurisdiction of Court of Appeal

Sittings of

Court of Appeal 
(2) The Court of Appeal shall be constituted by one judge when hearing an interlocutory matter.

Establishment

and

composition

of High

Court

Jurisdiction of High

Court

Sittings of High Court

Chief Justice
133. (1) There is established the High Court which consists of-

(a) the Chief Justice, as an ex-officio judge; and

(b) such number of judges as prescribed.

(2) There are established, as divisions of the High Court, the Industrial Relations Court, Commercial Court, Family Court and Children's Court.

(3) The Chief Justice may constitute, by statutory instrument, specialised courts of the High Court to hear specific matters.

(4) The composition of courts specified in clauses (2) and (3) shall be prescribed.

134. The High Court has, subject to Article 128-

(a) unlimited and original jurisdiction in civil and criminal matters;

(b) appellate and supervisory jurisdiction, as prescribed; and

(c) jurisdiction to review decisions, as prescribed.

135. The High Court shall be constituted by one judge or such other number of judges as the Chief Justice may determine.

\section{Chief Justice and other Judges}

136. (1) There shall be a Chief Justice who is the head of the Judiciary.

(2) The Chief Justice shall-

(a) be responsible for the administration of the Judiciary;

(b) ensure that a judge and judicial officer perform the judicial function with dignity, propriety and integrity;

(c) establish procedures to ensure that a judge and judicial officer independently exercise judicial authority in accordance with the law;

(d) ensure that a judge and judicial officer perform the judicial function without fear, favour or bias; and

(e) make rules and give directions necessary for the efficient and effective administration of the Judiciary. 
137. (1) There shall be a Deputy Chief Justice who shall-

(a) perform the functions of the Chief Justice, when the Chief Justice is absent or there is a vacancy in the office of Chief Justice;

(b) assist the Chief Justice in the administration of the Judiciary; and

(c) perform the functions assigned by the Chief Justice.

(2) The President shall, in consultation with the Judicial Service Commission, designate a judge of the Supreme Court to perform the functions of the Deputy Chief Justice where-

(a) the office of the Deputy Chief Justice is vacant;

(b) the Deputy Chief Justice is acting as Chief Justice; or

(c) the Deputy Chief Justice is for a reason unable to perform the functions of that office.

138. (1) There shall be a President of the Constitutional Court who is the head of the Constitutional Court.

(2) The President of the Constitutional Court shall be responsible for the administration of the Constitutional Court under the direction of the Chief Justice.

139. (1) There shall be a Deputy President of the Constitutional Court who shall-

(a) perform the functions of the President of the Constitutional

President of Constitutional Court

Deputy President of Constitutional Court Court, when the President of the Constitutional Court is absent or there is a vacancy in the office of President of the Constitutional Court;

(b) assist the President of the Constitutional Court in the administration of the Constitutional Court; and

(c) perform the functions assigned by the President of the Constitutional Court.

(2) The President shall, in consultation with the Judicial Service Commission, designate a judge of the Constitutional Court to perform the functions of the Deputy President of the Constitutional Court where-

(a) the office of the Deputy President of the Constitutional Court is vacant; 
(b) the Deputy President of the Constitutional Court is acting as President of the Constitutional Court; or

(c) the Deputy President of the Constitutional Court is for a reason unable to perform the functions of that office.

Appointment of judges

Qualification

for

appointment as judge

Tenure of office of judge
140. The President shall, on the recommendation of the Judicial Service Commission and subject to ratification by the National Assembly, appoint the-

(a) Chief Justice;

(b) Deputy Chief Justice;

(c) President of the Constitutional Court;

(d) Deputy President of the Constitutional Court; and

(e) other judges.

141. (1) A person qualifies for appointment as a judge if that person is of proven integrity and has been a legal practitioner, in the case of the-

(a) Supreme Court, for at least fifteen years;

(b) Constitutional Court, for at least fifteen years and has specialised training or experience in human rights or constitutional law;

(c) Court of Appeal, for at least twelve years; or

(d) High Court, for at least ten years.

(2) A person appointed as judge to a specialised court shall have the relevant expertise, as prescribed.

142. (1) A judge shall retire from office on attaining the age of seventy years.

(2) A judge may retire, with full benefits, on attaining the age of sixty-five years.

(3) The Chief Justice and President of the Constitutional Court shall hold office for not more than ten years and may, thereafter, continue as a judge of the Supreme Court or Constitutional Court, subject to clause (1).

(4) A judge who has retired is not eligible for appointment as a judge. 
(5) A judge may resign from the office of judge by notice, in writing, to the President.

(6) Where a judge is appointed or assigned to an office, which is not an office in the judiciary and that judge wishes to take up the appointment, the judge shall resign from the office of judge.

143. A judge shall be removed from office on the following grounds:

Removal of judge from office

(a) a mental or physical disability that makes the judge incapable of performing judicial functions;

(b) incompetence;

(c) gross misconduct; or

(d) bankruptcy.

144. (1) The removal of a judge may be initiated by the Judicial Complaints Commission or by a complaint made to the Judicial Complaints Commission, based on the grounds specified in Article

Procedure for removal of judge 143.

(2) The Judicial Complaints Commission shall, where it decides that a prima facie case has been established against a judge, submit a report to the President.

(3) The President shall, within seven days from the date of receiving the report, submitted in accordance with clause (2), suspend the judge from office and inform the Judicial Complaints Commission of the suspension.

(4) The Judicial Complaints Commission shall, within thirty days of the judge being suspended from office, in accordance with clause (3)-

(a) hear the matter against the judge on the grounds specified in Article 143 (b), (c) and (d); or

(b) constitute a medical board, in consultation with the body responsible for regulating health practitioners, to inquire into the matter against the judge based on the ground specified in Article 143(a). 
(5) Where the Judicial Complaints Commission decides that an allegation based on a ground specified in Article 143(b), (c) and (d) is-

(a) not substantiated, the Judicial Complaints Commission shall recommend, to the President, the revocation of the judge's suspension and the President shall immediately revoke the suspension; or

(b) substantiated, the Judicial Complaints Commission shall recommend, to the President, the removal of the judge from office and the President shall immediately remove the judge from office.

(6) The proceedings under clause (4) (a) shall be held in camera and the judge is entitled to appear, be heard and be represented by a legal practitioner or other person chosen by the judge.

(7) The medical board, constituted in accordance with clause (4) (b), shall consist of not less than three registered health practitioners.

(8) The medical board shall, within thirty days of being constituted, examine the judge and report to the Judicial Complaints Commission on the judge's capacity to perform the judicial functions.

(9) Where the medical board recommends to the Judicial Complaints Commission that the judge is-

(a) physically or mentally capable of performing the judicial functions, the Judicial Complaints Commission shall recommend to the President the revocation of the judge's suspension and the President shall immediately revoke the suspension; or

(b) not physically or mentally capable of performing the judicial functions, the Judicial Complaints Commission shall recommend to the President the removal of the judge from office and the President shall immediately remove the judge from office.

(10) A judge who refuses to submit to an examination, in accordance with clause (8), shall immediately be removed from office by the President. 


\section{Judicial Officers and Chief Administrator}

145. (1) The Judicial Service Commission shall appoint judicial officers, as prescribed.

(2) The qualification for appointment as judicial officer shall be prescribed.

(3) A judicial officer shall retire on attaining the age of sixtyfive years.

(4) A judicial officer may retire, with full benefits, on attaining the age of fifty-five years.

146. (1) There shall be a Chief Administrator for the Judiciary who shall be appointed by the Judicial Service Commission.

(2) The functions and qualifications of the Chief Administrator for the Judiciary shall be prescribed.

\section{PART IX \\ General Principles of Devolved Governance}

\section{System of Devolved Governance}

147. (1) The management and administration of the political, social, legal and economic affairs of the State shall be devolved from the national government level to the local government level.

Appointment and retirement of judicial officers
Chief

Administrator of Judiciary

(2) The concurrent and exclusive functions of the national, provincial and local government levels are as listed in the Annex and as prescribed.

(3) The different levels of government shall observe and adhere to the following principles:

(a) good governance, through democratic, effective and coherent governance systems and institutions;

(b) respect for the constitutional jurisdiction of each level of government;

(c) autonomy of the sub-structures; and

(d) equitable distribution and application of national resources to the sub-structures.

148. (1) Local governance shall be undertaken through substructures.

(2) The Government shall provide adequate resources for the

Substructures of local government performance of the functions of the sub-structures. 


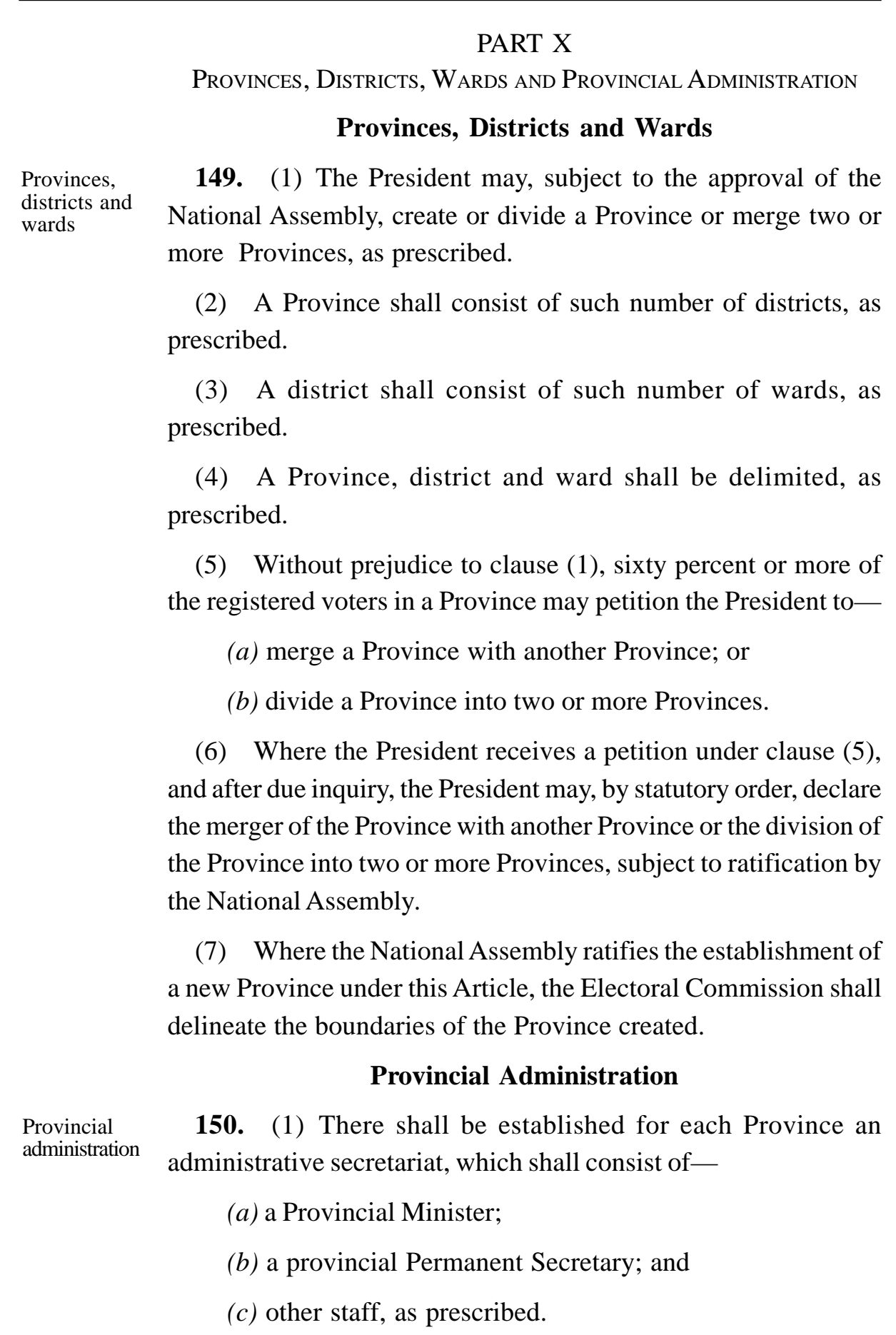

(2) The provincial secretariat shall have overall responsibility of the Province and perform other functions as prescribed. 


\section{PART XI}

\section{LOCAL GOVERnMENT \\ System of Local Government}

151. (1) There is established a local government system where-

(a) functions, responsibilities and resources from the national

System of

local

government Government and provincial administration are transferred to the local authorities in a co-ordinated manner;

(b) the people's participation in democratic governance is promoted;

(c) co-operative governance with the national Government, provincial administration and local authorities is promoted to support and enhance the developmental role of local government;

(d) the capacity of local authorities to initiate, plan, manage and execute policies in respect of matters that affect the people within their respective districts is enhanced;

(e) social, spatial, financial and economic planning, at the district level, is developed, prioritised and promoted;

( $f$ ) a sound financial base is established for each local authority with reliable and predictable sources of revenue;

(g) the performance of persons employed by the national Government and provincial administration to provide services in the sub-structures is overseen by local authorities;

(h) the provision of Government services is monitored and projects are implemented in sub-structures;

(i) accountability of local authorities is ensured; and

(j) the right of local authorities to manage their affairs and to form partnerships, networks and associations to assist in the management of their respective districts and further their development is recognised.

(2) The local government system shall-

(a) be based on democratically elected councils;

(b) promote democratic and accountable exercise of power;

(c) foster national unity; 
(d) ensure that services are provided to sub-structures in an equitable and sustainable manner;

(e) promote social and economic development;

( $f$ ) promote a clean, safe and healthy environment; and

(g) encourage the involvement of communities and community organisations in matters of local government.

152. (1) A local authority shall-

(a) administer the district;

(b) oversee programmes and projects in the district;

(c) make by-laws; and

(d) perform other prescribed functions.

(2)The national Government and the provincial administration shall not interfere with or compromise a local authority's ability or right to perform its functions.

(3) There shall be a council for each local authority.

(4) There shall be a Town Clerk or Council Secretary for each local authority and other staff of the local authority, as prescribed.

153. (1) A councillor shall be elected in accordance with Article 47(3) by registered voters resident within the district.

(2)A council shall consist of the following councillors-

(a) persons elected in accordance with clause (1);

(b) a mayor or council chairperson elected in accordance with Article 154; and

(c) not more than three chiefs representing chiefs in the district, elected by the chiefs in the district.

(3) The system of electing chiefs specified in clause (2) (b) shall be prescribed.

(4)A person qualifies to be elected as a councillor, excluding councillors specified under clause (2) (b), if that person-

(a) is not a Member of Parliament;

(b) is not less than nineteen years of age;

(c) has obtained, as a minimum academic qualification, a grade twelve certificate or its equivalent; 
(d) is a citizen or a holder of a resident permit, resident in the district; and

(e) has a certificate of clearance showing the payment of council taxes, where applicable.

(5) A council may invite a person, whose presence is in its opinion desirable, to attend and to participate in the deliberations of the council but that person shall have no vote.

(6) The term of a council shall be five years commencing from the date the councillors are sworn into office after a general election and ending on the date Parliament is dissolved.

154. (1) There shall be a mayor and deputy mayor or council chairperson and deputy council chairperson for every council, as prescribed.

(2) A mayor and council chairperson shall be elected-

(a) directly, in accordance with Article 47 (3) during elections for councillors, as prescribed; and

(b) for a term of five years and may be re-elected for one further term of five years.

(3)A deputy mayor and a deputy council chairperson shall be elected by the councillors from amongst themselves.

155. A councillor shall act in a manner that is consistent with a councillor's civic duties and responsibilities, as prescribed.

Conduct of councillor

156. Councillors shall be collectively and individually accountable to the national Government and residents in their wards and districts, for the performance of their functions.

157. (1) A councillor shall vacate office on dissolution of a council.

(2) The office of councillor becomes vacant if-

(a) the councillor ceases to be a resident of the district;

(b) the councillor resigns by one month's notice, in writing, to the mayor or council chairperson;

(c) the councillor becomes disqualified for election under Article 153;

(d) the result of an election for that councillor is nullified by a local government elections tribunal established in accordance with Article 159;

Accountability of councillors

Vacation of office of councillor and vacancies

Mayor, deputy council chairperson and deputy council

chairperson 
(e) the councillor acts contrary to the code of ethics provided for in Article 155;

(f) the councillor has a mental or physical disability that makes the councillor incapable of performing the functions of councillor; or

(g) the councillor dies.

(3) Where a councillor resigns in accordance with clause (2) (b), (c), (d) and (e) the councillor shall not be eligible for re-election as councillor for the duration of the term of that council.

By-election for council

Local government elections tribunals and petitions
158. (1) Where a vacancy occurs in the office of mayor, council chairperson or councillor-

(a) the Town Clerk or Council Secretary of the local authority shall, within seven days of the occurrence of the vacancy, inform the Electoral Commission, in writing, of the vacancy; and

(b) a by-election shall be held in accordance with Article 57.

(2) If a person is elected to the office of mayor, council chairperson or councillor in a by-election, that mayor, council chairperson or councillor shall serve for the unexpired term of the council and be deemed-

(a) to have served a full term as mayor, council chairperson or councillor if, at the date on which the councillor assumed office, at least three years remain before the date of the next general election; or

(b) not to have served a term of office as mayor, council chairperson or councillor, if, at the date on which the councillor assumed office, less than three years remain before the date of the next general election.

159. (1) The Chief Justice shall establish such number of ad hoc local government elections tribunals as are necessary to hear whether-

(a) a person has been validly elected as a councillor; or

(b) the office of a councillor has become vacant.

(2) A local government elections tribunal shall be presided over by a magistrate of competent jurisdiction sitting with two legal practitioners appointed by the Chief Justice. 
(3) A person may file an election petition with a local government elections tribunal to challenge the election of a councillor.

(4) An election petition shall be heard within thirty days of the filing of the petition.

(5) A person may appeal a decision of a local government elections tribunal to the Constitutional Court.

(6) A councillor whose election is petitioned shall hold the seat in the council pending the determination of the election petition.

(7) The Chief Justice shall make rules for the functions, composition, appointment of members, tenure of office of members, procedures and jurisdiction of a local government elections tribunal.

160. A person who obtains a judgment against a local authority may enforce the judgment against the local authority after one year from the date of the delivery of the judgment.

161. A local authority is competent to levy, impose, recover and retain local taxes, as prescribed.

162. (1) There is established the Constituency Development Fund.

Enforcement of judgment against local authority

Revenue of local authorities

Constituency Development Fund

(2) The appropriation of monies to the Constituency Development Fund and the management, disbursement, utilisation and accountability of the Constituency Development Fund shall be prescribed.

163. (1) There is established the Local Government Equalisation Fund.

(2) Parliament shall annually appropriate monies to the Local Government Equalisation Fund which shall be disbursed by the Ministry responsible for finance to local authorities.

(3)The Government may provide additional funds and grants to a local authority, as prescribed.

164. The following shall be prescribed:

(a) regulation of local authorities;

(b) sub-structures and their relationships;

authorities

(c) financial control and accountability of a local authority;

(d) raising of loans, grants and other financial instruments by local authorities; 
(e) election of councillors; and

( $f$ ) the effective implementation of this Part.

PART XII

\section{Chieftaincy and House of Chiefs}

Institution of chieftaincy and

traditional institutions

Status of institution of chieftaincy

Rights and privileges of
chiefs

Participation of chiefs in public affairs

House of Chiefs and function
165. (1) The institution of chieftaincy and traditional institutions are guaranteed and shall exist in accordance with the culture, customs and traditions of the people to whom they apply.

(2) Parliament shall not enact legislation which-

(a) confers on a person or authority the right to recognise or withdraw the recognition of a chief; or

(b) derogates from the honour and dignity of the institution of chieftaincy.

166. The institution of chieftaincy-

(a) is a corporation sole with perpetual succession and capacity to sue and be sued; and

(b) has capacity to hold property in trust for its subjects.

167. A chief-

(a) may own property in a personal capacity; and

(b) shall enjoy privileges and benefits-

(i) bestowed on the office of chief by or under culture, custom and tradition; and

(ii) attached to the office of chief, as prescribed.

168. (1) Subject to clause (2), a chief may seek and hold a public office.

(2) A chief who seeks to hold office in a political party or election or appointment to a State office, except that of councillor, shall abdicate the chief's throne.

(3) The role of a chief in the management, control and sharing of natural and other resources in the Chiefdom shall be prescribed.

169. (1) There is established a House of Chiefs.

(2) The House of Chiefs shall consist of five chiefs from each province, elected by the chiefs in a Province, as prescribed. 
(3) The members of the House of Chiefs shall annually elect a Chairperson and Vice-Chairperson of the House of Chiefs, from amongst themselves.

(4) Notwithstanding clause (3), the assumption of office as Chairperson and Vice-Chairperson of the House of Chiefs shall rotate annually amongst the chiefs from each province.

(5) The functions of the House of Chiefs are to -

(a) consider and discuss a Bill relating to custom or tradition referred to it by the President, before the Bill is introduced into the National Assembly;

(b) initiate, discuss and make recommendations to the National Assembly regarding socio-economic development in the Province;

(c) initiate, discuss and decide on matters relating to customary law and practice;

(d) initiate, discuss and make recommendations to a local authority regarding the welfare of communities in a local authority;

(e) make proposals on areas in customary law that require codification;

(f) advise the Government on traditional and customary matters; and

(g) perform other functions as prescribed.

170. (1) A Member of the House of Chiefs-

(a) shall hold office for a term of five years and is eligible for election for a further term of five years; and

(b) may resign by one month's notice, in writing, to the Chairperson.

(2) The office of a member of the House of Chiefs becomes vacant if the Chief-

(a) dies;

(b) ceases to be a chief;

(c) resigns; 
(d) is convicted of an offence;

(e) is an undischarged bankrupt; or

( $f$ ) has a mental or physical disability that makes the chief incapable of performing the functions of a member of the House of Chiefs.

Staff of House of Chiefs

Legislation on House of Chiefs

Values and principles of public service
171. (1) There shall be a Clerk of the House of Chiefs and other staff, as prescribed.

(2) The office of the Clerk of the House of Chiefs and other staff of the House of Chiefs are offices in the public service.

172. The following matters shall be prescribed-

(a) the procedures and processes of the House of Chiefs;

(b) the emoluments of the Clerk and other staff of the House of Chiefs;

(c) the application of the privileges and immunities of a Member of Parliament to a member of the House of Chiefs; and

(d) other matters necessary for the better carrying out of the purposes of this Part.

\section{PART XIII \\ Public Service}

\section{Values and Principles}

173. (1) The guiding values and principles of the public service include the following-

(a) maintenance and promotion of the highest standards of professional ethics and integrity;

(b) promotion of efficient, effective and economic use of national resources;

(c) effective, impartial, fair and equitable provision of public services;

(d) encouragement of people to participate in the process of policy making;

(e) prompt, efficient and timely response to people's needs;

(f) commitment to the implementation of public policy and programmes;

(g) accountability for administrative acts; 
(h) proactively providing the public with timely, accessible and accurate information;

(i) merit as the basis of appointment and promotion;

(j) adequate and equal opportunities for appointments, training and advancement of members of both gender and members of all ethnic groups; and

(k) representation of persons with disabilities in the composition of the public service at all levels.

(2) The values and principles specified in clause (1) apply to service-

(a) at national, provincial and local government levels; and

(b) to all State organs and State institutions.

(3) A public officer shall not be-

(a) victimised or discriminated against for having performed functions in good faith in accordance with this Constitution or other law; or

(b) removed from office, reduced in rank or otherwise punished without just cause and due process.

\section{Constituting Offices for Public Service}

174. (1) Subject to the recommendations of the relevant Service Commission, the power to constitute offices for the public service and to abolish those offices vests in the President.

Constituting offices for public service

(2) The President shall not abolish an office in the public service while there is a substantive holder of the office.

(3) The President may, by statutory instrument, declare that an office constituted by the President shall not be an office in the public service.

(4) Appointment to an office declared by the President not to be an office in the public service shall be made by the President.

175. For the purposes of this Constitution, a person shall not be considered as holding an office in the public service by reason only that the person is in receipt of emoluments in respect of service under or for the Government. 


\section{Constitutional Office Holders}

Secretary to Cabinet
176. (1) There shall be a Secretary to the Cabinet who shall be appointed by the President, in consultation with the Civil Service Commission, subject to ratification by the National Assembly.

(2) The Secretary to the Cabinet shall-

(a) be chief advisor to the President on the management of the public service;

(b) be the head of the public service and responsible to the President for securing the general efficiency and effectiveness of the public service;

(c) ensure that public services are delivered to the public efficiently;

(d) in accordance with instructions of the President-

(i) arrange the affairs of Cabinet;

(ii) attend meetings of Cabinet;

(iii) cause to be written and kept minutes of meetings of Cabinet; and

(iv) convey decisions made by Cabinet to appropriate authorities;

(e) monitor the implementation of Government policies and Cabinet decisions; and

(f) perform other functions as prescribed.

(3) A person qualifies to be appointed as Secretary to the Cabinet if that person has or had at least ten years experience as a permanent secretary or equivalent rank.

(4) The term of office of the Secretary to the Cabinet shall be five years, subject to renewal for further terms.

(5) The Secretary to the Cabinet may resign from office by giving three months' notice, in writing, to the President.

AttorneyGeneral
177. (1) There shall be an Attorney-General, who shall be appointed by the President, subject to ratification by the National Assembly.

(2) The Attorney-General shall not hold another public office.

(3) The Attorney-General shall be a person qualified to be appointed as a judge. 
(4) The Attorney-General shall not be subject to the direction or control of a person or an authority in the performance of the Attorney-General's functions.

(5) The Attorney-General is the chief legal adviser to the Government and shall-

(a) be head of the Attorney-General's Chambers;

(b) sign Government Bills to be presented to the National Assembly;

(c) represent the Government in civil proceedings to which Government is a party;

(d) give advice on an agreement, treaty or convention to which Government intends to become a party or in respect of which the Government has an interest before they are concluded, except where the National Assembly otherwise directs, and subject to conditions as prescribed; and

(e) perform other functions, as prescribed.

(6) The Attorney-General's Chambers shall be devolved to the Provinces and progressively to districts.

178. (1) The office of the Attorney-General becomes vacant if-

(a) the Attorney-General is removed from office by the President;

(b) another person assumes the office of President;

(c) the Attorney-General dies; or

(d) the Attorney-General has a mental or physical disability that makes the Attorney-General incapable of performing the functions of that office.

(2) The Attorney-General may resign from office by giving three months' notice, in writing, to the President.

179. (1) There shall be a Solicitor-General who shall be appointed by the President, subject to ratification by the National Assembly.

(2) A person qualifies for appointment as Solicitor-General if that person is qualified for appointment as a judge.

(3) The Solicitor-General shall not hold another public office. 
(4) The office of Solicitor-General becomes vacant if-

(a) the Solicitor-General is removed from office by the President;

(b) another person assumes the office of President;

(c) the Solicitor-General dies; or

(d) the Solicitor-General has a mental or physical disability that makes the Solicitor-General incapable of performing the functions of that office.

(5) The Solicitor-General shall assist the Attorney-General in the performance of the Attorney- General's functions.

(6) A function conferred on the Attorney-General by this Constitution or other law shall be performed by the Solicitor-General when the Attorney-General is unable to act owing to illness or absence from office for a reason.

(7) The Solicitor-General may resign from office by giving three months' notice, in writing, to the President.

Director of Public Prosecutions
180. (1) There shall be a Director of Public Prosecutions who shall be appointed by the President, subject to ratification by the National Assembly.

(2) A person qualifies for appointment as Director of Public Prosecutions if that person-

(a) has experience in undertaking criminal trials; and

(b) is qualified to be appointed as a judge.

(3) The Director of Public Prosecutions is the chief prosecutor for the Government and head of the National Prosecutions Authority.

(4)The Director of Public Prosecutions may-

(a) institute and undertake criminal proceedings against a person before a court, other than a court-martial, for an offence alleged to have been committed by that person;

(b) take over and continue criminal proceedings instituted or undertaken by another person or authority; and

(c) discontinue, at any stage before judgment is delivered, criminal proceedings instituted or undertaken by the Director of Public Prosecutions or another person or authority. 
(5) For the purposes of clause (4), an appeal from a judgment, a case stated or to a question of law reserved shall be part of the criminal proceedings.

(6) The power conferred on the Director of Public Prosecutions under clause $(4)(c)$ shall not be exercised in relation to an appeal by a convicted person, a case stated or a question of law reserved at the instance of that person.

(7) The Director of Public Prosecutions shall not be subject to the direction or control of a person or an authority in the performance of the functions of that office, except that the Director of Public Prosecutions shall have regard to the public interest, administration of justice, the integrity of the judicial system and the need to prevent and avoid abuse of the legal process.

(8)The functions of the Director of Public Prosecutions may be exercised in person or by a public officer or legal practitioner, authorised by the Director of Public Prosecutions, acting under the general or special instructions of the Director of Public Prosecutions.

(9) The National Prosecutions Authority shall be established as prescribed and shall devolve to the provinces and progressively to the districts.

181. Where the Director of Public Prosecutions is absent from Zambia or is unable to perform the functions of office due to illness or other cause, the President shall appoint a person qualified to perform the functions of Director of Public Prosecutions to perform those functions until that appointment is revoked or until the Director of Public Prosecutions returns to office.

182. (1) Subject to this Article, the Director of Public Prosecutions shall retire from office on attaining the age of sixty years.

(2) The Director of Public Prosecutions may retire, with full benefits, on attaining the age of fifty-five years.

(3) The Director of Public Prosecutions may be removed from office on the same grounds and procedure as apply to a judge.

(4) The Director of Public Prosecutions may resign from office by three months' notice, in writing, to the President. functions

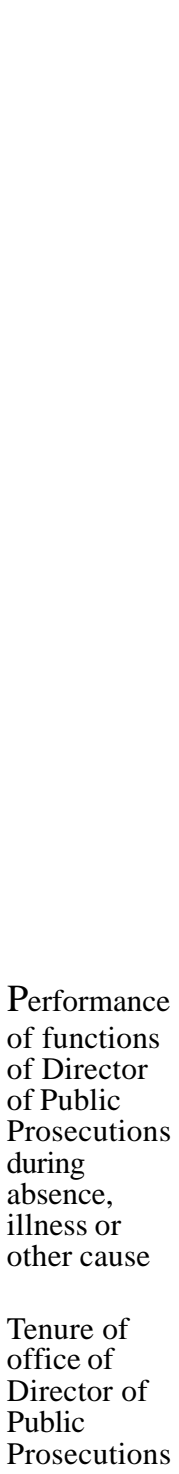


Secretary to Treasury
183. (1) There shall be a Secretary to the Treasury who shall be appointed by the President, in consultation with the Civil Service Commission, subject to ratification by the National Assembly.

(2) The Secretary to the Treasury shall be the chief controlling officer of the Government.

(3) The Secretary to the Treasury shall-

(a) be responsible and accountable for-

(i) the proper financial management and expenditure of public monies appropriated to a State organ, Province, local authority, State institution or other prescribed body; and

(ii) monies raised from sources within or outside Zambia by a Province, local authority, State institution or other prescribed body;

(b) oversee the formulation and implementation of the macroeconomic frameworks and socio-economic plans of the Republic;

(c) provide a regulatory framework for sound financial management;

(d) cause to be prepared annual estimates of revenue and expenditure, supplementary estimates of expenditure and the budget; and

(e) carry out other prescribed functions.

(4) A person qualifies to be appointed as Secretary to the Treasury if that person qualifies for appointment as Governor of the Bank of Zambia.

(5) The term of office of the Secretary to the Treasury shall be five years, subject to renewal for further terms.

(6) The Secretary to the Treasury may resign from office by three months' notice, in writing, to the President.

Permanent Secretaries

184. (1) The President shall, on the advice of the Civil Service Commission, appoint a Permanent Secretary for a Province, ministry or department.

(2) A Permanent Secretary shall-

(a) carry out or cause to be carried out the portfolio functions of the provincial administration, ministry or department; 
(b) advise the Minister or provincial Minister with respect to the activities, projects and programmes of the Province, ministry or department;

(c) cause to be implemented the policies of the Government and decisions of Cabinet;

(d) be responsible and accountable for the proper financial management and expenditure of public monies appropriated to the Province, ministry or department; and

(e) be responsible and accountable for the management of human resources in the provincial secretariat, ministry or department.

\section{Public Officers}

185. (1) The President has, in accordance with and subject to the other provisions of this Constitution, the power to-

(a) appoint and confirm public officers;

Appointment of public officers

(b) exercise disciplinary control over public officers; and

(c) terminate the employment of a public officer.

(2) The President's functions, as specified in clause (1), shall be exercised by the relevant Service Commission as specified in this Constitution and as prescribed.

(3) A person shall not be regarded as disqualified for appointment to an office to which a public officer is qualified to be appointed by reason only that the office is held by a person who is on leave of absence pending relinquishment of that office.

(4) A function of a service commission may be delegated to a public officer, as prescribed.

186. (1) A public officer who seeks election, or is appointed, to a State office shall resign.

Participation in politics

(2) Clause (1) applies to a Constitutional office holder.

\section{PART XIV \\ Pension Benefit}

187. (1) An employee, including a public officer and Constitutional office holder, has a right to a pension benefit.

(2) A pension benefit shall not be withheld or altered to that employee's disadvantage. 
(3) The law to be applied with respect to a pension benefit-

(a) before the commencement of this Constitution, shall be the law that was in force immediately before the date on which the pension benefit was granted or the law in force at a later date that is not less favourable to that employee; and

(b) after the commencement of this Constitution, shall be the law in force on the date on which the pension benefit was granted or the law in force at a later date that is not less favourable to that employee.

Review of pension benefit and tax exemption

Payment of pension benefits

Principles relating to Defence Force and national security services

Status of Defence Force and national security services
188. (1) A pension benefit shall be reviewed periodically to take into account actuarial assessments.

(2) A pension benefit shall be exempt from tax.

189. (1) A pension benefit shall be paid promptly and regularly.

(2) Where a pension benefit is not paid on a person's last working day, that person shall stop work but the person's name shall be retained on the payroll, until payment of the pension benefit based on the last salary received by that person while on the payroll.

\section{PART XV \\ Defence and National Security}

190. (1) The Defence Force and national security services shall-

(a) be nationalistic, patriotic, professional, disciplined and competent;

(b) be non-partisan;

(c) not further the interests or cause of a particular organisation; and

(d) not act against a political interest or cause permitted in this Constitution or as prescribed.

(2) Clause (1) shall not prevent a member of the Defence Force and national security services from registering as a voter or voting in an election or a referendum.

191. The Defence Force and national security services shall be-

(a) subordinate to civilian authority, as vested in the State organs; and 
(b) adequately and properly equipped to enable them effectively perform their functions.

192. (1) There is established the Defence Force of Zambia consisting of-

(a) the Zambia Army;

Establishment

of Defence

Force and

(b) the Zambia Air Force;

(c) the Zambia National Service, as an auxiliary unit; and

(d) other units, as prescribed.

(2) The Defence Force shall-

(a) preserve and defend the sovereignty and territorial integrity of the Republic;

(b) foster harmony and understanding between the Zambia Army, Zambia Air Force, an auxiliary unit and members of society; and

(c) co-operate with State organs and State institutions in times of public emergencies and national disasters.

193. (1) There are established the following national security services-

(a) the Zambia Police Service;

Establishment of national security services and

(b) the Zambia Security Intelligence Service;

(c) the Zambia Correctional Service; and

(d) any other national security service, as prescribed.

(2) The Zambia Police Service shall-

(a) protect life and property;

(b) preserve peace and maintain law and order;

(c) ensure the security of the people;

(d) detect and prevent crime;

(e) uphold the Bill of Rights;

(f) foster and promote good relationships with the Defence Force, other national security services and members of society; and

(g) perform other functions as prescribed. 
(3) The Zambia Security Intelligence Service shall-

(a) ensure national security by undertaking security intelligence and counter intelligence;

(b) prevent a person from suspending, overthrowing or illegally abrogating this Constitution; and

(c) perform other functions as prescribed.

(4) The Zambia Correctional Service shall-

(a) manage, regulate and ensure the security of prisons and correctional centres; and

(b) perform other functions as prescribed.

Qualification to serve in Defence Force and national security service

Deployment outside Republic
Prohibition of activities relating to defence and national security

Legislation on Defence Force and national security services
194. A person is qualified to serve as a member of the Defence Force and national security services if the person is-

(a) a citizen who does not hold dual citizenship; and

(b) qualified as prescribed.

195. (1) The President may deploy personnel of the Defence Force outside the Republic.

(2) Where the President deploys personnel of the Defence Force outside the Republic, the President shall, as soon as is reasonably practicable, inform the National Assembly of the deployment.

196. Except as provided in this Constitution, a person shall not-

(a) raise or participate in the raising of an armed force;

(b) establish or participate in the establishment of a defence force or national security service; or

(c) establish or participate in the establishment of a unit of the Defence Force or national security service.

197. The following shall be prescribed:

(a) the regulation of the Defence Force and national security services;

(b) the organs and structures of the Defence Force and national security services;

(c) the operations and administration of the Defence Force and national security services;

(d) the recruitment of persons into the Defence Force and national security services, which shall reflect the regional diversity of the people of Zambia; 
(e) the appointment, qualifications, placement, transfer, discipline and retirement of defence and security chiefs and other personnel of the Defence Force and national security services;

( $f$ ) the emoluments of personnel and members of the Defence Force and national security services;

(g) the procedures and processes for deployment of the personnel of the Defence Force; and

(h) other functions as prescribed.

\section{PART XVI \\ Public Finance and Budget}

198. The guiding principles of public finance include the following:

(a) transparency and accountability in the development or

formulation of macro-economic frameworks, socioeconomic plans and the budget;

(b) promotion of a public finance system that ensures that-

(i) the burden of taxation is shared fairly;

(ii) revenue raised nationally is shared equitably among the different levels of government; and

(iii) expenditure promotes the equitable development of the country;

(c) sustainable public borrowing to ensure inter-generational equity; and

(d) prudent and responsible use of public resources.

199. (1) A tax shall not be imposed, except as prescribed.

(2) Where legislation confers power on a person or an authority to waive or vary a prescribed tax the power shall be exercised through a statutory instrument.

(3) A report explaining the waiver or variation of a tax shall be submitted to the National Assembly within twenty-one days of the publication of the statutory instrument.

200. (1) There is established a Consolidated Fund to which shall be credited the revenues and other monies accruing to the Treasury.

Imposition of tax 
(2) Clause (1) does not apply to monies-

(a) prescribed for a public fund established for a specific purpose; or

(b) that a State organ or State institution may retain for the purpose of defraying the expenses of the State organ or State institution, as prescribed.

Withdrawal from

Consolidated

Fund

Annual

financial estimates of revenue and expenditure
201. (1) Monies shall not be withdrawn from the Consolidated Fund except-

(a) to meet expenditure charged on the Consolidated Fund by this Constitution or as prescribed; or

(b) where the issuance of those monies has been authorised by a warrant signed by the President, an Appropriation Act or a Supplementary Appropriation Act in accordance with Article 203.

(2) The investment or lending of monies forming part of the Consolidated Fund, in accordance with Articles 206 and 207, respectively, shall not be considered a withdrawal from the Consolidated Fund.

202. (1) The Minister responsible for finance shall prepare and lay before the National Assembly in each financial year, not later than ninety days before the commencement of the next financial year, estimates of revenue and expenditure for the Republic.

(2) The Minister responsible for finance shall, when presenting the estimates of revenue and expenditure, in accordance with clause (1), specify the maximum limits that the Government intends to borrow or lend in that financial year.

(3) In a year where a general election is held, the Minister responsible for finance shall cause to be prepared and laid before the National Assembly, within ninety days of the swearing in of the President, estimates of revenue and expenditure for the Republic for the next financial year.

(4) The National Assembly may vary estimates of revenue and expenditure but shall not amend the total amount of estimates of revenue and expenditure.

(5) The National Assembly shall, by a resolution of the Members of Parliament, approve the financial estimates of revenue and expenditure for the next financial year. 
203. (1) Where estimates of revenue and expenditure have been approved by the National Assembly in accordance with Article 202, the Minister responsible for finance shall lay, before the National Assembly for enactment, an Appropriation Bill in respect of the approved estimates of expenditure.

(2) The Minister responsible for finance shall, where the Appropriation Act, Supplementary Appropriation Act and Excess Expenditure Appropriation amount appropriated in an Appropriation Act for a financial year is insufficient to meet expenditure in that financial year, lay before the National Assembly for approval, in accordance with Article 202 (5), a supplementary estimate of expenditure.

(3) Where a supplementary estimate of expenditure has been approved by the National Assembly, the Minister responsible for finance shall lay, before the National Assembly for enactment, a Supplementary Appropriation Bill in respect of the approved supplementary estimate of expenditure.

(4) Where there is an urgent need to incur expenditure for a purpose that has not been appropriated under the Appropriation Act for that financial year and it would not be in the public interest to delay the appropriation of the expenditure until a supplementary estimate is approved by the National Assembly, in accordance with clauses (2) and (3), the President may, subject to Article 204, issue a warrant authorising the expenditure and withdrawal from the Consolidated Fund.

(5) The Minister responsible for finance shall present the warrant referred to in clause (4) to the relevant parliamentary committee for approval.

(6) The parliamentary committee shall consider the warrant within forty-eight hours of its presentation by the Minister responsible for finance.

(7) Where expenditure is incurred in accordance with clause (4), the Minister responsible for finance shall, in that financial year, lay an Excess Expenditure Appropriation Bill before the National Assembly for enactment.

(8) Where it is not practicable to lay an Excess Expenditure Appropriation Bill before the National Assembly, in accordance with clause (7), the Minister responsible for finance shall lay the Excess Expenditure Appropriation Bill before the National Assembly during the first sitting of the National Assembly after the end of the preceding financial year. 
Limitation

and

conditions of

warrant

Budget and

planning

legislation

Investment of public funds

Borrowing and lending by

Government
204. (1) The issuance of a warrant, in accordance with Article 203 (4), shall be subject to limitations and conditions, as prescribed.

(2) The President shall, immediately after signing a warrant in accordance with Article 203 (4), cause a copy of the warrant to be transmitted to the Auditor-General and Parliament.

205. The following shall be prescribed:

(a) the financial management and regulation of public funds;

(b) the preparation of medium and long-term financing frameworks and development plans;

(c) the budget preparation process;

(d) public participation, at all levels of government, in the formulation of financing frameworks, development plans and preparation of annual budgets;

(e) the content of the financial report of the Republic provided for in Article 211; and

(f) the control and disbursement of appropriated funds.

206. (1) Monies forming part of the Consolidated Fund may be invested into readily marketable securities and deposits or other secure investments, with a financial institution approved by the Minister responsible for finance.

(2) The investment of monies made in accordance with clause (1) shall be prescribed.

207. (1) The Government may, as prescribed-

(a) raise a loan or grant on behalf of itself, a State organ, State institution or other institution;

(b) guarantee a loan on behalf of a State organ, State institution or other institution; or

(c) enter into an agreement to give a loan or grant out of the Consolidated Fund, other public fund or public account.

(2) Legislation enacted under clause (1) shall provide-

(a) for the category, nature and other terms and conditions of a loan, grant or guarantee, that will require the approval by the National Assembly before the loan, grant or guarantee is executed; and 
(b) that any monies received in respect of a loan or grant approved by the National Assembly shall be paid into the Consolidated Fund, or other public fund or public account.

208. (1) A public debt shall be a charge on the Consolidated Fund or other public fund.

(2) For the purposes of this Article, "public debt" includes the interest on that debt, sinking fund payments in respect of that debt and the costs, charges and expenses incidental to the management of that debt.

209. (1) There is established a Compensation Fund for the purpose of settling claims against the State.

(2) The management of the Compensation Fund shall be prescribed.

210. (1) A State organ, State institution and other public office shall procure goods or services, in accordance with a system that is fair, equitable, transparent, competitive and cost-effective, as prescribed.

(2) A major State asset shall be sold, transferred or otherwise disposed of, as prescribed, subject to the approval of the National Assembly signified by a vote of at least two-thirds of the Members of Parliament.

(3) For the purposes of this Article, "major State asset" includes a parastatal and equity held by the Government, as prescribed.

211. (1) The Minister responsible for finance shall, within three months after the end of each financial year, prepare and submit to the Auditor-General the financial report of the Republic in respect Financial report of Republic of the preceding financial year.

(2) The Auditor-General shall, within two months of receipt of the financial report, examine the financial report and express an opinion on the report.

(3) The Minister responsible for finance shall, within one month after the receipt of the Auditor-General's opinion, lay the financial report, with the Auditor-General's opinion, before the National Assembly.

(4) The financial report shall include information on-

(a) revenue received by the Republic during that financial year; 
(b) the expenditure of the Republic during that financial year;

(c) gifts, donations and aid-in-kind received on behalf of the Republic in that financial year, their value and how they were disposed of;

(d) debt repayments;

(e) payments made in that financial year for purposes other than expenditure;

(f) the financial position of the Republic at the end of that financial year; and

(g) other information as prescribed.

AuditorGeneral's report

Bank of Zambia

Governor of Bank of

Zambia
212. The Auditor-General shall, not later than nine months after the end of a financial year, submit an audit report to the President and the National Assembly, on the accounts of the Republic audited in respect of the preceding financial year.

\section{PART XVII \\ Central Bank}

213. (1) There is established the Bank of Zambia which shall be the central bank of the Republic.

(2) The functions of the Bank of Zambia are to-

(a) issue the currency of the Republic;

(b) determine monetary policy; and

(c) regulate banking and financial services, banks, financial and non-banking institutions, as prescribed.

(3) There is constituted a Board of Directors for the Bank of Zambia whose composition shall be prescribed.

(4) The functions of the Bank of Zambia vest in the Board of Directors and shall be performed as prescribed.

(5) The Bank of Zambia shall not be subject to the direction or control of a person or an authority in the performance of its functions.

214. (1) There shall be a Governor of the Bank of Zambia who shall be appointed by the President, subject to ratification by the National Assembly, and who shall be-

(a) a citizen; 
(b) a person who has specialised training and experience in economics, finance, accounting, banking, law or other field relevant to banking, as prescribed; and

(c) a person of proven integrity.

(2) The Governor shall be the Chairperson of the Board of Directors.

215. The following shall be prescribed:

(a) additional functions, operations and management of the Bank of Zambia;

(b) appointment, qualifications and tenure of office of the Board of Directors;

(c) election of a Vice-Chairperson of the Board of Directors;

(d) tenure of office and emoluments of the Governor;

(e) appointment, qualifications, tenure of office, functions and emoluments of the Deputy-Governor;

(f) recruitment, and emoluments of members of staff of the Bank of Zambia; and

(g) other matters necessary for the performance of the functions of the Bank of Zambia.

\section{PART XVIII}

Services, Commissions and Other Independent Offices

216. A commission shall-

(a) be subject only to this Constitution and the law;

Principles

relating to

commissions

(b) be independent and not be subject to the control of a person or an authority in the performance of its functions;

(c) act with dignity, professionalism, propriety and integrity;

(d) be non-partisan; and

(e) be impartial in the exercise of its authority.

\section{Parliamentary Service Commission}

217. (1) There is established the Parliamentary Service.

(2) The office of the Clerk of the National Assembly, members Parliamentary Service. 
Parliamentary Service

Commission Commission.

(2) The Parliamentary Service Commission shall-

(a) appoint the Clerk of the National Assembly;

(b) constitute offices in the Parliamentary Service;

(c) appoint, confirm, promote and hear appeals from officers of the Parliamentary Service;

(d) ensure efficient and effective functioning of the National Assembly;

(e) have financial oversight of the Parliamentary Service and the National Assembly; and

(f) perform such other functions as prescribed.

\section{Judicial Service Commission}

Judicial Service

Judicial

Service

Commission

Civil Service
219. (1) There is established the Judicial Service.

(2) The office of judge, judicial officer, the members of staff of the Judicial Service Commission and such other officers as prescribed, are offices in the Judicial Service.

220. (1) There is established the Judicial Service Commission.

(2) The Judicial Service Commission shall-

(a) constitute offices in the Judicial Service;

(b) make recommendations to the President on the appointment of judges;

(c) appoint, confirm, promote and hear appeals from judicial officers; and

(d) carry out a function provided for in this Constitution, or as prescribed.

\section{Civil Service Commission}

221. (1) There is established the Civil Service.

(2) The office of the Secretary to the Cabinet, Secretary to the Treasury, Deputy Secretary to the Cabinet, civil servants, the members of staff of the Civil Service Commission and other public officers as prescribed, are offices in the Civil Service. 
222. (1) There is established the Civil Service Commission.

(2) The Civil Service Commission shall-

(a) constitute offices in the Civil Service;

(b) appoint, confirm, promote and hear appeals from officers in the Civil Service, excluding a Constitutional office holder; and

(c) perform such other functions as prescribed.

\section{Teaching Service Commission}

223. (1) There is established the Teaching Service.

(2) The teachers serving as public officers excluding civil Teaching Service servants, the members of staff of the Teaching Service Commission and other public officers, as prescribed, are offices in the Teaching Service.

224. (1) There is established the Teaching Service Commission.

(2) The Teaching Service Commission shall-

Teaching

Service

Commission

(a) constitute offices in the Teaching Service;

(b) appoint, confirm, promote and hear appeals from officers of the Teaching Service; and

(c) perform such other functions as prescribed.

\section{Zambia Correctional Service Commission}

225. (1) There is established the Zambia Correctional Service Commission for the Zambia Correctional Service established in Article 193.

Zambia

Correctional

Service

Commission

(2) The office of Commissioner-General of Correctional Service, Deputy Commissioners-General of Correctional Service, Commissioners of Correctional Service, Assistant Commissioners of Correctional Service, Correctional officers and wardens, members of staff of the Zambia Correctional Service Commission and such other public officers as prescribed, are offices in the Zambia Correctional Service.

(3) The Zambia Correctional Service Commission shall-

(a) constitute offices in the Zambia Correctional Service;

(b) appoint, confirm, promote and hear appeals from officers of the Zambia Correctional Service; and

(c) perform such other functions as prescribed. 


\section{Zambia Police Service Commission}

Zambia

Police

Service

Commission

Government

Service

Local

Government

Service

Commission Commission of Zambia
226. (1) There is established the Zambia Police Service Commission for the Zambia Police Service established in Article 193.

(2) The office of the Inspector-General of Police, the Deputy Inspector-General of Police, police officers, the members of staff of the Zambia Police Service Commission and other public officers as prescribed, are offices in the Zambia Police Service.

(3) The Zambia Police Service Commission shall-

(a) constitute offices in the Zambia Police Service;

(b) appoint, confirm, promote and hear appeals from officers of the Zambia Police Service; and

(c) perform such other functions as prescribed.

\section{Local Government Service Commission}

227. (1) There is established the Local Government Service.

(2) The office of the Town Clerk, Council Secretary, members of staff of the Local Government Service Commission, the members of staff of local authorities and other local government staff, as prescribed, are offices in the Local Government Service.

228. (1) There is established the Local Government Service Commission.

(2) The Local Government Service Commission shall-

(a) appoint the Town Clerk and Council Secretary of a local authority;

(b) constitute offices in the Local Government Service;

(c) appoint, confirm, promote and hear appeals from officers of the Local Government Service;

(d) ensure efficient and effective functioning of local authorities; and

(e) perform such other functions as prescribed.

\section{Electoral Commission of Zambia}

229. (1) There is established the Electoral Commission of Zambia which shall have offices in Provinces and progressively in districts. 
(2) The Electoral Commission shall-

(a) implement the electoral process;

(b) conduct elections and referenda;

(c) register voters;

(d) settle minor electoral disputes, as prescribed;

(e) regulate the conduct of voters and candidates;

( $f$ ) accredit observers and election agents, as prescribed;

(g) delimit electoral boundaries; and

(h) perform such other functions as prescribed.

\section{Human Rights Commission}

230. (1) There is established the Human Rights Commission which shall have offices in the Provinces and progressively in districts.

(2) The Human Rights Commission shall ensure that the Bill of Rights is upheld and protected.

(3) The Human Rights Commission shall-

(a) investigate and report on the observance of rights and freedoms;

(b) take necessary steps to secure appropriate redress where rights and freedoms are violated;

(c) endeavour to resolve a dispute through negotiation, mediation or conciliation;

(d) carry out research on rights and freedoms and related matters;

(e) conduct civic education on rights and freedoms; and

( $f$ ) perform such other functions as prescribed.

\section{Gender Equity and Equality Commission}

231. (1) There is established the Gender Equity and Equality Commission which shall have offices in the Provinces and progressively in districts.

Human

Rights

Commission

(2) The Gender Equity and Equality Commission shall promote the attainment and mainstreaming of gender equality. 
(3) The Gender Equity and Equality Commission shall-

(a) monitor, investigate, research, educate, advise and report on issues concerning gender equality;

(b) ensure institutions comply with legal requirements and other standards relating to gender equality;

(c) take steps to secure appropriate redress to complaints relating to gender inequality, as prescribed; and

(d) perform such other functions as prescribed.

\section{Emoluments Commission}

Emoluments Commission

Lands

Commission

State Audit Commission

Investigative Commissions
232. (1) There is established the Emoluments Commission.

(2) The Emoluments Commission shall determine, on the recommendation of the relevant authority or commission, the emoluments of public officers, chiefs and members of the House of Chiefs, as provided in this Constitution or as prescribed.

\section{Lands Commission}

233. (1) There is established the Lands Commission which shall have offices in all Provinces and progressively in districts.

(2) The Lands Commission shall administer, manage and alienate land, on behalf of the President, as prescribed.

\section{State Audit Commission}

234. (1) There is established the State Audit Commission.

(2) The State Audit Commission shall-

(a) subject to Article 249 (2) oversee the operations of the office of the Auditor-General, as prescribed;

(b) make recommendations to the President on the appointment of the Auditor-General; and

(c) perform such other functions as prescribed.

\section{Investigative Commissions}

235. There is established the following investigative commissions:

(a) the Anti-Corruption Commission;

(b) the Drug Enforcement Commission; and

(c) the Anti-Financial and Economic Crimes Commission. 


\section{Judicial Complaints Commission}

236. (1) There is established the Judicial Complaints Commission.

(2) The Judicial Complaints Commission shall-

Judicial

Complaints

Commission

(a) enforce the Code of Conduct for judges and judicial officers;

(b) ensure that judges and judicial officers are accountable to the people for the performance of their functions;

(c) receive complaints lodged against a judge or judicial officer, as prescribed;

(d) hear a complaint against a judge or judicial officer, as prescribed;

(e) make recommendations to the appropriate institution or authority for action; and

( $f$ ) perform such other functions as prescribed.

\section{Police Public Complaints Commission}

237. (1) There is established the Police Public Complaints Commission.

(2) The Police Public Complaints Commission shall-

(a) receive and investigate complaints against police actions;

(b) investigate complaints against police actions which result in serious injury or death of a person;

(c) make recommendations to the appropriate institution or authority for action; and

(d) perform such other functions as prescribed.

\section{General Provisions Relating to Commissions}

238. (1) A commission shall be a self-accounting institution which deals directly with the Ministry responsible for finance in matters relating to its finances.

(2) A commission shall be adequately funded in a financial year to enable it to effectively perform its functions.

239. The expenses of a commission, including emoluments payable to, or in respect of, persons serving with that commission, shall be a charge on the Consolidated Fund.
Police Public Complaints Commission

Financial independence of

commissions

Expenses of commissions 
Qualifications of members of

commissions

powers of commissions

Legislation on commissions

Public Protector
240. A person qualifies to be appointed as a member of a commission if that person-

(a) is a citizen;

(b) is permanently resident in Zambia;

(c) has not, in the immediate preceding five years, served a term of imprisonment of at least three years;

(d) declares that person's assets and liabilities, as prescribed;

(e) has paid that person's taxes or has made arrangements satisfactory to the appropriate tax authority for the payment of the taxes;

(f) does not have a mental or physical disability that would make the person incapable of performing the functions of office;

(g) is not serving a sentence of imprisonment for an offence under a law; and

(h) has other qualifications, as prescribed.

241. A commission-

(a) shall appoint its staff;

(b) may refer matters within its mandate to appropriate State organs or State institutions for action;

(c) may initiate its own investigations and receive complaints from a person on matters within its mandate;

(d) shall take measures to ensure that State institutions and other persons comply with its decisions; and

(e) shall submit annual reports to the National Assembly on its accounts and activities as prescribed.

242. The functions, composition, appointment of members, tenure of office of members, processes and procedures, operations, administration, structures, finances and financial management of a commission shall be prescribed.

\section{Other Independent Offices Public Protector}

243. (1) There shall be a Public Protector who shall be appointed by the President, on the recommendation of the Judicial Service Commission, subject to ratification by the National Assembly. 
(2) A person qualifies for appointment as Public Protector if that person-

(a) is qualified to be appointed as a judge; and

(b) does not hold a State office or Constitutional office.

(3) The office of Public Protector shall be decentralised to the Provinces and progressively to districts, as prescribed.

(4) The procedures, staff, finances, financial management, administration and operations of the office of the Public Protector shall be prescribed.

244. (1) The Public Protector may investigate an action or decision taken or omitted to be taken by a State institution in the performance of an administrative function.

(2) For purposes of clause (1), an action or decision taken or omitted to be taken is an action or decision which is-

(a) unfair, unreasonable or illegal; or

(b) not compliant with the rules of natural justice.

(3) For purposes of clauses (1) and (2), the Public Protector may-

(a) bring an action before a court;

(b) hear an appeal by a person relating to an action or decision taken or omitted to be taken in respect of that person; and

(c) make a decision on an action to be taken against a public officer or Constitutional office holder, which decision shall be implemented by an appropriate authority.

(4) The Public Protector shall not be subject to the direction or control of a person or an authority in the performance of the functions of office.

(5) The Public Protector has the same powers as those of the High Court in-

(a) enforcing the attendance of witnesses and examining them on oath;

(b) examining witnesses outside Zambia;

(c) compelling the production of documents;

(d) enforcing decisions issued by the Public Protector; and

(e) citing a person or an authority for contempt for failure to carry out a decision. 
(6) A person summoned to give evidence or to produce a document before the Public Protector is entitled, in respect of that evidence or the production of the document, to the same privileges and protection as those that a person would be entitled to before a court.

(7) An answer by a person to a question put by the Public Protector is not admissible in evidence against that person in civil or criminal proceedings, except for perjury.

Limitation of powers of Public

Protector

Performance of functions of Public Protector during absence, illness or other cause

Tenure of office of Public Protector

Report to National Assembly

AuditorGeneral
245. The Public Protector shall not investigate a matter which-

(a) is before a court, court martial or a quasi-judicial body;

(b) relates to an officer in the Parliamentary Service or Judicial Service;

(c) involves the relations or dealings between the Government and foreign government or an international organisation;

(d) relates to the exercise of the prerogative of mercy; or

(e) is criminal in nature.

246. Where the Public Protector is absent from Zambia or is unable to perform the functions of office due to illness or other cause, the President shall appoint a person qualified to perform the functions of the Public Protector until that appointment is revoked or until the Public Protector returns to office.

247. (1) Subject to this Article, the Public Protector shall retire from office on attaining the age of sixty years.

(2) The Public Protector may retire, with full benefits, on attaining the age of fifty-five years.

(3) The Public Protector may be removed from office on the same grounds and procedure as apply to a judge.

(4) The Public Protector may resign from office by three months' notice, in writing, to the President.

248. The office of the Public Protector shall report to the National Assembly on matters concerning its affairs.

\section{Auditor-General}

249. (1) There shall be an Auditor-General who shall be appointed by the President, on the recommendation of the State Audit Commission, subject to ratification by the National Assembly. 
(2) The office of Auditor-General shall be decentralised to the Provinces and progressively to districts, as prescribed.

(3) The following shall be prescribed:

(a) the qualifications of the Auditor-General;

(b) the operations and management of the office of the Auditor-General;

(c) the recruitment, supervision, grading, promotion and discipline of the staff of the Auditor-General; and

(d) the finances of the office of the Auditor-General.

250. (1) The Auditor-General shall-

(a) audit the accounts of-

(i) State organs, State institutions, provincial administration and local authorities; and

(ii) institutions financed from public funds;

(b) audit the accounts that relate to the stocks, shares and stores of the Government;

(c) conduct financial and value for money audits, including forensic audits and any other type of audit, in respect of a project that involves the use of public funds;

(d) ascertain that money appropriated by Parliament or raised by the Government and disbursed-

(i) has been applied for the purpose for which it was appropriated or raised;

(ii) was expended in conformity with the authority that governs it; and

(iii) was expended economically, efficiently and effectively; and

(e) recommend to the Director of Public Prosecutions or a law enforcement agency any matter within the competence of the Auditor-General, that may require to be prosecuted.

(2) The Auditor-General shall not be subject to the direction or control of a person or an authority in the performance of the functions of office.
Functions of

Auditor-

General 
Performance of functions of AuditorGeneral during absence, illness or other cause

Tenure of office of AuditorGeneral

Principles of land policy
251. Where the Auditor-General is absent from Zambia or is unable to perform the functions of office due to illness or other cause, the President shall appoint a person qualified to perform the functions of the Auditor-General until that appointment is revoked or until the Auditor-General returns to office.

252. (1) Subject to this Article, the Auditor-General shall retire from office on attaining the age of sixty years.

(2) The Auditor-General may retire, with full benefits, on attaining the age of fifty-five years.

(3) The Auditor-General may be removed from office on the same grounds and procedure as apply to a judge.

(4) The Auditor-General may resign from office by three months' notice, in writing, to the President.

\section{PART XIX \\ Land, Environment and Natural Resources}

\section{Land}

253. (1) Land shall be held, used and managed in accordance with the following principles:

(a) equitable access to land and associated resources;

(b) security of tenure for lawful land holders;

(c) recognition of indigenous cultural rites;

(d) sustainable use of land;

(e) transparent, effective and efficient administration of land;

( $f$ ) effective and efficient settlement of land disputes;

$(g)$ river frontages, islands, lakeshores and ecologically and culturally sensitive areas-

(i) to be accessible to the public;

(ii) not to be leased, fenced or sold; and

(iii) to be maintained and used for conservation and preservation activities;

(h) investments in land to also benefit local communities and their economy; and

(i) plans for land use to be done in a consultative and participatory manner. 
254. (1) Land shall be delimited and classified as State land, customary land and such other classification, as prescribed.

(2) The President may, through the Lands Commission, alienate land to citizens and non-citizens, as prescribed.

(3) Land shall be held for a prescribed tenure.

\section{Environment and Natural Resources}

255. The management and development of Zambia's environment and natural resources shall be governed by the following principles:

(a) natural resources have an environmental, economic, social and cultural value and this shall be reflected in their Principles of environmental and natural resources management and use;

(b) the person responsible for polluting or degrading the environment is responsible for paying for the damage done to the environment;

(c) where there are threats of serious or irreversible damage to the environment, lack of full scientific certainty shall not be used as a reason for postponing cost-effective measures to prevent environmental degradation;

(d) the conservation and protection of ecologically sensitive areas, habitats, species and other environment shall be done in a sustainable manner;

(e) respect for the integrity of natural processes and ecological communities;

(f) benefits accruing from the exploitation and utilisation of the environment and natural resources shall be shared equitably amongst the people of Zambia;

(g) saving of energy and the sustainable use of renewable energy sources shall be promoted;

(h) reclaiming and rehabilitation of degraded areas and those prone to disasters shall be promoted;

(i) unfair trade practices in the production, processing, distribution and marketing of natural resources shall be eliminated;

(j) origin, quality, methods of production, harvesting and processing of natural resources shall be regulated; 
(k) equitable access to environmental resources shall be promoted;

(l) effective participation of people in the development of relevant policies, plans and programmes; and

(m) access to environmental information to enable people preserve, protect and conserve the environment.

Protection of environment and natural resources

Utilisation of natural resources and management of environment

Official language and use and status of local languages
256. A person has a duty to co-operate with State organs, State institutions and other persons to-

(a) maintain a clean, safe and healthy environment;

(b) ensure ecologically sustainable development and use of natural resources;

(c) respect, protect and safeguard the environment; and

(d) prevent or discontinue an act which is harmful to the environment.

257. The State shall, in the utilisation of natural resources and management of the environment-

(a) protect genetic resources and biological diversity;

(b) implement mechanisms that minimise waste;

(c) promote appropriate environment management systems and tools;

(d) encourage public participation;

(e) protect and enhance the intellectual property in, and indigenous knowledge of, biodiversity and genetic resources of local communities;

(f) ensure that the environmental standards enforced in Zambia are of essential benefit to citizens; and

(g) establish and implement mechanisms that address climate change.

\section{PART XX \\ General Provisions}

258. (1) The official language of Zambia is English.

(2) A language, other than English, may be used as a medium of instruction in educational institutions or for legislative, administrative or judicial purposes, as prescribed.

(3) The State shall respect, promote and protect the diversity of the languages of the people of Zambia. 
259. (1) Where a person is empowered to make a nomination or an appointment to a public office, that person shall ensure-

(a) that the person being nominated or appointed has the requisite qualification to discharge the functions of the office, as prescribed or specified in public office circulars or establishment registers;

(b) that fifty percent of each gender is nominated or appointed from the total available positions, unless it is not practicable to do so; and

(c) equitable representation of the youth and persons with disabilities, where these qualify for nomination or appointment.

(2) A person empowered to make a nomination or appointment to a public office shall, where possible, ensure that the nomination or appointment reflects the regional diversity of the people of Zambia.

260. A person assuming a public office, member of the House of Chiefs, and presidential appointee, shall take an Oath of Office and such other oath, as prescribed, before carrying out the duties of office.

261. A person holding a public office shall act in accordance with a code of conduct and ethics, as prescribed for that office.

262. A person holding a public office shall not act in a manner, or be in a position, where the personal interest of that person conflicts, or is likely to conflict, with the performance of the functions of office.

263. A person holding a public office shall, before assuming office or leaving office, make a declaration of their assets and liabilities, as prescribed.

264. (1) A public officer, chief and member of the House of Chiefs, shall be paid such emoluments as recommended by the relevant authority or commission and determined by the Emoluments Commission.

(2) The emoluments of a State officer, councillor, Constitutional office holder and a judge shall be determined by the Emoluments Commission, as prescribed.
Nominations and appointments

Oath of office and prescribed oaths

Code of conduct and ethics

Conflict of interest

Declaration of assets

Emoluments payable under Constitution 
(3) The emoluments of a person holding a public office, chief and member of the House of Chiefs shall not be altered to the disadvantage of that person during that person's tenure of office.

(4) A person holding a public office shall not, while in office, hold another office which pays emoluments.

Funding, expenses and emoluments charge on Consolidated Fund

Definitions
265. (1) A public office shall be adequately funded to enable it to effectively perform its functions.

(2) The expenses of a State organ, State institution and public office shall be a charge on the Consolidated Fund.

(3) The emoluments payable under this Constitution or as prescribed, shall be a charge on the Consolidated Fund.

266. In this Constitution, unless the context otherwise requires-

" adult" means a person who has attained, or is above, the age of nineteen years;

“ Bill " means a draft of a proposed law to be enacted by Parliament;

" Bill of Rights " means the human rights and fundamental freedoms set out in Part III, and includes their status, application, interpretation, limitations, derogations, nonderogations and enforcement;

" by-election" means an election to fill a vacancy in the office of a Member of Parliament or councillor;

“ candidate " means a person contesting a presidential, parliamentary or local government election;

" chief " means a person bestowed as chief and who derives allegiance from the fact of birth or descent, in accordance with the customs, traditions, usage or consent of the people in a chiefdom;

" child" means a person who has attained, or is below, the age of eighteen years;

“ circuit schedule" means a table showing dates, districts, time and place where a court is to sit and hear matters in any period of twelve months; 
“ citizen ” means a citizen of Zambia;

" civil servant" means a public officer appointed by the Civil Service Commission;

“ civil society" means a group of persons, who are not part of the Government, who associate for the purpose of advancing or protecting particular interests;

“ commission” means a commission established under Part XVIII of this Constitution;

“constituency" means an area into which Zambia is divided for purposes of elections to the National Assembly;

" Constitutional Court " means the Constitutional Court established in this Constitution;

"Constitutional office " means the office of the AttorneyGeneral, Solicitor-General, Director of Public Prosecutions, Public Protector, Auditor-General, Secretary to the Cabinet, Secretary to the Treasury and Permanent Secretary;

“ Constitutional office holder" means a person holding or acting in a Constitutional office;

“council ” includes a city, municipal or town council;

“ council chairperson ” means a person elected chairperson of a town council in accordance with Article 154;

" councillor" means a member of a council elected in accordance with Article 153;

“ court” means a court of competent jurisdiction established by or under this Constitution;

"Court of Appeal " means the Court of Appeal established in this Constitution;

“ devolution " means a form of decentralisation where there is a transfer of rights, functions and powers or an office from the central government or State institution to a subnational authority or the bringing of a service that is provided at central government level to, or opening of a branch of a public office or institution at, a sub- national level, and the word "devolved” shall be construed accordingly; 
“ disability” means a permanent physical, mental, intellectual or sensory impairment that alone, or in combination with social or environmental barriers, hinders the ability of a person to fully or effectively participate in an activity or perform a function as specified in this Constitution or as prescribed;

" discrimination" means directly or indirectly treating a person differently on the basis of that person's birth, race, sex, origin, colour, age, disability, religion, conscience, belief, culture, language, tribe, pregnancy, health, or marital, ethnic, social or economic status;

" district " means an administrative unit of a Province as provided in Article 149;

" election " means an election to the office of President, National Assembly or a council;

“Electoral Commission" means the Electoral Commission of Zambia established in this Constitution;

“ emoluments ” include salaries, allowances, benefits and rights that form an individual's remuneration for services rendered, including pension benefits or other benefits on retirement;

“Emoluments Commission" means the Emoluments Commission established in this Constitution;

" executive authority" means the power and the right to execute executive functions;

" executive functions" means the functions of the President set out in this Constitution;

“ ex-officio" means a person who is appointed as a member by virtue of office;

“First Deputy Speaker " means the person elected as First Deputy Speaker in accordance with Article 82 (4);

“ freedom fighter " means a person who fought for the independence of the former protectorate of Northern Rhodesia to become the Republic of Zambia; 
“ function ” includes powers and duties;

" gender" means female or male and the role individuals play in society as a result of their sex and status;

“ general election ” means Presidential, National Assembly and local government elections when held on the same day;

“ gross misconduct” means-

(a) behaviour which brings a public office into disrepute, ridicule or contempt;

(b) behaviour that is prejudicial or inimical to the economy or the security of the State;

(c) an act of corruption; or

(d) using or lending the prestige of an office to advance the private interests of that person, members of that person's family or another person;

“ health practitioner" means a person registered as a health practitioner as prescribed;

" High Court" means the High Court established in this Constitution;

“ individual ” means a natural person;

“ judge ” means a person appointed as a judge of a superior court;

“ judgment" includes a decision, an order or decree of a court or an authority, as prescribed;

“ judicial authority” means the power and right to perform judicial functions;

“ judicial function ” means the functions of the Judiciary set out in this Constitution;

“ judicial officer" includes a magistrate, local court magistrate, registrar and such officers as prescribed;

"legislative authority" means the power and right to perform legislative functions; 
"legislative functions" means the functions of the legislature set out in this Constitution;

“ local authority” means a council and it's secretariat consisting of persons appointed by the Local Government Service Commission;

" local government" means governance at the local level;

“ local government elections tribunal ” means a tribunal established in accordance with Article 159;

“ Local Government Equalisation Fund ” means a fund established in accordance with Article 163;

“ mayor” means a person elected mayor of a city or municipal council in accordance with Article 154;

"Member of Parliament " means a person who is member of the National Assembly;

“ Minister ” means a Cabinet Minister;

“ oath ” includes an affirmation;

“ older member of society " means a person who has attained, or is above, the age of sixty years;

“opposition ” means a political party which is not the political party in government;

“ ordinarily resident" means residing in a place for a prescribed period of time;

“Parliament” means the President and the National Assembly;

“parliamentary committee " means a committee established in accordance with Article 80;

“pension benefit” includes a pension, compensation, gratuity or similar allowance in respect of a person's service;

" person " means an individual, a company or an association of persons, whether corporate or unincorporate;

“ person with disability" means a person with a permanent physical, mental, intellectual or sensory impairment; 
" political party" means an association whose objectives include the contesting of elections in order to form government or influence the policy of the national or local government;

“power” includes privilege, authority and discretion;

“ prescribed " means provided for in an Act of Parliament;

“President-elect" means the presidential candidate who has been declared by the Returning Officer as having won the presidential election;

“presidential candidate " means a person nominated to stand for election as President in accordance with Article 52 (1);

" presidential election" means an election to the office of President, and includes the election of a Vice-President as a running mate to the President;

“property " includes a vested or contingent right to, or interest in, or arising from-

(a) land, permanent fixtures on, or improvements to, land;

(b) goods or personal property;

(c) intellectual property; or

(d) money, choses in action or negotiable instruments;

" provincial administration" means the administrative secretariat established in accordance with Article 150;

“Provincial Minister" means a person appointed Provincial Minister by the President;

“public media " means media owned, operated or controlled by the Government;

" public office" means an office whose emoluments and expenses are a charge on the Consolidated Fund or other prescribed public fund and includes a State office, Constitutional office and an office in the public service, including that of a member of a commission; 
" public officer" means a person holding or acting in a public office, but does not include a State officer, councillor, a Constitutional office holder, a judge and a judicial officer;

" public service" means service in the Civil Service, the Teaching Service, Defence Force and National Security Service, the Zambia Correctional Service, the Zambia Police Service, Emoluments Commission, State Audit Commission, Lands Commission, Electoral Commission, Human Rights Commission, Gender Equity and Equality Commission, the Anti-Corruption Commission, Drug Enforcement Commission, the Anti-Financial and Economic Crimes Commission, the Police and Public Complaints Commission, and service as a constitutional office holder, service in other offices, as prescribed;

“ rights and freedoms " means the human rights and fundamental freedoms provided for in the Bill of Rights;

“ Republic” means the Republic of Zambia;

“ returning officer" means a person who is a returning officer for a parliamentary or local authority election and "Returning Officer" means the Chairperson of the Electoral Commission in a presidential election;

“ running mate" means a person who is selected by a presidential candidate to stand with the presidential candidate in a presidential election so that the person becomes the Vice-President if that presidential candidate is elected as President;

"Second Deputy Speaker " means the person elected as Second Deputy Speaker in accordance with Article 82 (5);

"Service Commission " means a commission established under Articles 218, 220, 222, 224, 225, 226, and 228;

" session" means a period not exceeding twelve months, within the term of the National Assembly, of sittings of the National Assembly, which commence on the first day of sitting after a general election or prorogation of Parliament and ends with a prorogation or dissolution of Parliament; 
" sitting " means a meeting of the National Assembly, within a session, which concludes with an adjournment, and includes a parliamentary committee meeting;

“Speaker" means the person elected Speaker of the National Assembly in accordance with Article 82 (1);

"State institution " includes a ministry or department of the Government, a public office, agency, institution, statutory body, commission or company in which the Government or local authority has a controlling interest, other than a State organ;

"State office" includes the office of President, VicePresident, Speaker, Deputy Speaker, Member of Parliament, Minister and Provincial Minister;

"State officer" means a person holding or acting in a State office;

"State organ " means the Executive, Legislature or Judiciary;

“ statutory instrument " means a proclamation, regulation, rule, by-law, order or other similar legal instrument made under a power conferred by this Constitution or an Act of Parliament;

" subordinate court" means a court subordinate to the High Court;

“ sub-national " means an administrative division of government at provincial or district level;

“ sub-structure ” includes a district, ward and village;

“ superior court " means the Supreme Court, Constitutional Court, Court of Appeal and High Court established in accordance with this Constitution;

" Supreme Court ” means the Supreme Court established in this Constitution;

“ tax " includes rates, levies, charges, tariffs, fees, tolls and duties;

" term " means a period of five years commencing when the National Assembly first sits, after a general election, and ending when Parliament is dissolved; 
“ Treasury" means the office, in the Ministry responsible for finance, which receives, keeps, receipts, manages and disburses public funds;

“Vice-President-elect " means the person declared as having been duly elected as a Vice-President after a presidential election;

" ward " means a unit into which a district is divided for purposes of electing councillors;

"young person " means a person who has attained the age of fifteen years, but is below the age of nineteen years; and

"youth " means a person who has attained the age of nineteen years, but is below the age of thirty-five years.

Interpretation

of

Constitution
267. (1) This Constitution shall be interpreted in accordance with the Bill of Rights and in a manner that-

(a) promotes its purposes, values and principles;

(b) permits the development of the law; and

(c) contributes to good governance.

(2) If there is a conflict between the English version of this Constitution and a different language version, the English version shall prevail.

(3) A provision of this Constitution shall be construed according to the doctrine that the law is continuously in force and accordingly-

(a) a function may be performed, as occasion requires, by the person holding the office to which the function is assigned;

(b) a reference to a person holding an office includes a reference to the person lawfully performing the functions of that office at a particular time;

(c) a reference to an office, State organ, State institution or locality shall be read with any modification necessary to make it applicable in the circumstances;

(d) a reference in a provision applying that provision to another provision shall be read with any modification necessary to make it applicable in the circumstances and any reference to the modified provision shall apply as modified; and 
(e) a reference to an office, body or organisation, where that office, body or organisation has ceased to exist, is a reference to its successor or to the equivalent office, body or organisation performing the functions.

(4) A provision of this Constitution to the effect that a person, an authority or institution is not subject to the direction or control of a person or an authority in the performance of a function, does not preclude a court from exercising jurisdiction in relation to a question as to whether that person, authority or institution has performed the function in accordance with this Constitution or other laws.

268. In this Constitution, unless the context otherwise requires-

(a) a word in the singular includes the plural and a word in Grammatical variation the plural includes the singular; and

(b) a word or expression defined, shall be read with any grammatical variation or similar expression of that word or expression.

269. For the purposes of this Constitution, in computing time, unless a contrary intention is expressed-

(a) a period of days from the happening of an event or the doing of an act shall be considered to be exclusive of the day on which the event happens or the act is done;

(b) if the last day of the period is a Saturday, Sunday or public holiday ("excluded day"), the period shall include the next day;

(c) where an act or a proceeding is directed or allowed to be done or taken on a specified day and that day is an excluded day, the act or proceeding shall be considered as done or taken in due time if it is done or taken the next day; and

(d) where an act or a proceeding is directed or allowed to be done or taken within a time not exceeding six days, an excluded day shall not be counted in the computation of the time. 
Power to appoint includes power to remove

Implied power

Legislation to give effect to

Constitution

Power to make statutory instrument, resolution or direction

Time for performance of function

Exercise of power between publication and commencement of Acts
270. In this Constitution, unless a contrary intention is expressed, power to appoint a person to hold or act in an office includes the power to confirm appointments, to exercise disciplinary control over the person holding or acting in the office and to remove that person from office.

271. In this Constitution, a power given to a person or an authority to do or enforce the doing of an act, includes the necessary and ancillary powers to enable that person or authority to do or enforce the doing of the act.

272. Parliament may enact legislation to give effect to an Article or a provision in this Constitution which-

(a) confers a function or jurisdiction on a person, office, institution, council or commission;

(b) provides for a process or procedure to be taken, followed or prescribed;

(c) requires an action, a measure or decision to be taken or provided;

(d) requires a remedy or compensation to be given;

(e) prohibits an action or measure;

(f) deals with a specific subject-matter or general matter that would require to be legislated on in order to give effect to the Constitution; or

(g) generally requires something to be prescribed.

273. In this Constitution, a power conferred on a person or an authority to make a statutory instrument, a resolution or direction, includes the power to amend or revoke the statutory instrument, resolution or direction.

274. A function conferred in this Constitution may be performed as occasion requires.

275. Where an Article provides for a power exercisable by making a statutory instrument to-

(a) make an appointment; or

(b) do any other thing for the purposes of the Article;

the power may be exercised at any time on or after the date of publication of the statutory instrument in the Gazette. 


\section{ANNEX}

(Article 147 (2))

\section{Functions of National, Provincial and Local Levels of} DeVOLVED GOVERNMENT

\section{A. Exclusive national functions}

$\cdot$ Elections

- Foreign and international affairs

- Budget

- Taxation including customs and excise

- Airports, other than district airports

- Casinos, racing, gambling and wagering, excluding lotteries and sports pools

- Disaster management and public emergency

- National parks, national botanical gardens and resources

- National forests

- passports and National Registration

$\cdot$ Prisons

$\cdot$ Refugees

- Registration of Births and Deaths

- Wildlife

- Water resources management

• Energy and hydro electricity

- Petroleum and lubricants

- Public roads

- Defence, security, maintenance of law and order

- Citizenship and immigration

- Public enterprises

- Regulation of commerce and manufacturing

- Road traffic regulation

- Land, mines, minerals and natural resources

- Census and statistics

- Traditional leadership

- National archives

- National libraries

- National museums

- Tertiary Education 


\section{B. Concurrent national and provincial functions}

- administration of justice

- legal affairs

- Administration of forests

- Agriculture

- Animal control and diseases

- Consumer protection

- Cultural matters

- Customary law

- Education at all levels, excluding tertiary education

- Environmental management

$\cdot$ Health services

$\cdot$ Housing

- Industrial promotion

- Language policy and the regulation of official languages

- Nature conservation

- Parliamentary Business

- legislative procedures and processess

- Pollution control

- Population development

- Property transfer tax

- Public procurement

- Public transport

- Public works only in respect of the needs of provincial administration

- Provincial spatial planning and development

- Soil conservation

- Tourism, trade and commerce

- Urban and rural development

- Welfare services

$\cdot$ Industrial and labour relations

- Resettlement

- Investment

- Telecommunication 


\section{Local Authorities exclusive functions}

- Pollution control

- Building regulations

- Child-care facilities

- Electricity

- Fire fighting services

- Local tourism

- District airports, Aerodromes and Airships

- District planning

- District health services

- District public transport

- District public works only in respect of the needs of Districts in the discharge of councils responsibilities to administer functions specifically assigned to them under this Constitution or other law

$\cdot$ Levies, tariffs and tolls

- Pontoons, ferries, jetties, piers and harbours, excluding the regulation of international and national shipping and matters related thereto

- Storm water management systems in built-up areas

- Trading

-Water and sanitation services limited to potable water supply systems and domestic waste-water and sewage disposal systems

- Veterinary services, excluding regulation of the veterinary profession

- Vehicle licensing

- Abattoirs

- Ambulance services

- Archives

$\cdot$ Libraries

- Liquor licencing

$\cdot$ Museums 
- Local spatial planning

- Cultural matters

- Recreation and amenities

-Sport

- Roads and traffic automation and maintenance

-Amusement facilities

- Billboards and the display of advertisements in public places

- Cemeteries, funeral parlours and crematoria

$\cdot$ Local cleansing

- Control of public nuisances

- Control of undertakings that sell liquor to the public

- Facilities for the accommodation, care and burial of animals

- Fencing and fences

- Licensing of dogs

- Licensing and control of undertakings that sell food to the public

- Local amenities

- Local sport facilities

- Markets

- Local parks and recreation

- Local roads

- Noise pollution

- Pounds

- Public places

- Refuse removal, refuse dumps and solid waste disposal

- Street trading

- Street lighting

- Traffic and parking

- Gardens and landscaping 